\title{
Chelate Control of Diiron(I) Dithiolates Relevant to the [Fe-Fe]- Hydrogenase Active Site
}

\author{
Aaron K. Justice ${ }^{\dagger}$, Giuseppe Zampella ${ }^{\ddagger}$, Luca De Gioia ${ }^{*}, \ddagger$, Thomas B. Rauchfuss ${ }^{\star}, \dagger$, Jarl Ivar \\ van der Vlugt ${ }^{\dagger}$, and Scott R. Wilson ${ }^{\dagger}$ \\ Department of Chemistry, University of Illinois, Urbana, Illinois 61801, and Department of \\ Biotechnology and Biosciences, University of Milano-Bicocca, Piazza della Scienza 1, 20126 Milan, \\ Italy
}

\begin{abstract}
The reaction of $\mathrm{Fe}_{2}\left(\mathrm{~S}_{2} \mathrm{C}_{2} \mathrm{H}_{4}\right)(\mathrm{CO})_{6}$ with cis- $\mathrm{Ph}_{2} \mathrm{PCH}=\mathrm{CHPPh}_{2}$ (dppv) yields $\mathrm{Fe}_{2}\left(\mathrm{~S}_{2} \mathrm{C}_{2} \mathrm{H}_{4}\right)$ $(\mathrm{CO})_{4}(\mathrm{dppv}), \mathbf{1}(\mathrm{CO})_{4}$, wherein the dppv ligand is chelated to a single iron center. NMR analysis indicates that in $\mathbf{1}(\mathrm{CO})_{4}$, the dppv ligand spans axial and basal coordination sites. In addition to the axial-basal isomer, the 1,3-propanedithiolate and azadithiolate derivatives exist as dibasal isomers. Density functional theory (DFT) calculations indicate that the axial-basal isomer is destabilized by nonbonding interactions between the dppv and the central $\mathrm{NH}$ or $\mathrm{CH}_{2}$ of the larger dithiolates. The $\mathrm{Fe}(\mathrm{CO})_{3}$ subunit in $\mathbf{1}(\mathrm{CO})_{4}$ undergoes substitution with $\mathrm{PMe}_{3}$ and cyanide to afford $\mathbf{1}(\mathrm{CO})_{3}\left(\mathrm{PMe}_{3}\right)$ and $\left(\mathrm{Et}_{4} \mathrm{~N}\right)\left[\mathbf{1}(\mathrm{CN})(\mathrm{CO})_{3}\right]$, respectively. Kinetic studies show that $\mathbf{1}(\mathrm{CO})_{4}$ reacts faster with donor ligands than does its parent $\mathrm{Fe}_{2}\left(\mathrm{~S}_{2} \mathrm{C}_{2} \mathrm{H}_{4}\right)(\mathrm{CO})_{6}$. The rate of reaction of $\mathbf{1}(\mathrm{CO})_{4}$ with $\mathrm{PMe}_{3}$ was first order in each reactant, $k=3.1 \times 10^{-4} \mathrm{M}^{-1} \mathrm{~s}^{-1}$. The activation parameters for this substitution reaction, $\Delta H^{\ddagger}=5.8(5) \mathrm{kcal} / \mathrm{mol}$ and $\Delta S^{\ddagger}=-48(2) \mathrm{cal} / \mathrm{deg} \cdot \mathrm{mol}$, indicate an associative pathway. DFT calculations suggest that, relative to $\mathrm{Fe}_{2}\left(\mathrm{~S}_{2} \mathrm{C}_{2} \mathrm{H}_{4}\right)(\mathrm{CO})_{6}$, the enhanced electrophilicity of $\mathbf{1}(\mathrm{CO})_{4}$ arises from the stabilization of a "rotated" transition state, which is favored by the unsymmetrically disposed donor ligands. Oxidation of $\mathrm{MeCN}$ solutions of $\mathbf{1}(\mathrm{CO})_{3}\left(\mathrm{PMe}_{3}\right)$ with $\mathrm{Cp}_{2} \mathrm{FePF}_{6}$ yielded $\left[\mathrm{Fe}_{2}\left(\mathrm{~S}_{2} \mathrm{C}_{2} \mathrm{H}_{4}\right)(\mu-\mathrm{CO})(\mathrm{CO})_{2}(\mathrm{dppv})\left(\mathrm{PMe}_{3}\right)(\mathrm{NCMe})\right]\left(\mathrm{PF}_{6}\right)_{2}$. Reaction of this compound with $\mathrm{PMe}_{3}$ yielded $\left[\mathrm{Fe}_{2}\left(\mathrm{~S}_{2} \mathrm{C}_{2} \mathrm{H}_{4}\right)(\mu-\mathrm{CO})(\mathrm{CO})(\mathrm{dppv})\left(\mathrm{PMe}_{3}\right)_{2}(\mathrm{NCMe})\right]\left(\mathrm{PF}_{6}\right)_{2}$.
\end{abstract}

\section{Introduction}

The design of first-row metal centers capable of catalyzing redox interconversions of hydrogen is a major goal of contemporary science. ${ }^{1}$ The structural analyses of the active sites of the two major families of hydrogenases has provided the information required for generating structural models. Replicating the reactivity of the enzymes has, however, proven far more challenging. More progress has been achieved in modeling the [Fe-Fe]-hydrogenases than modeling of the nickel-iron enzymes, 2,3 and it is increasingly clear to us that further advances will follow from greater control of the ligands and the redox poise of the diiron center.

The active site of the $[\mathrm{Fe}-\mathrm{Fe}]-$ hydrogenases feature a diiron tricarbonyl center that can be described as $\left[\mathrm{Fe}_{2}(\mathrm{SR})_{2}-(\mathrm{CO})_{3} \mathrm{~L}_{3} \mathrm{H}_{n}\right]^{z}\left(n=0,1 ; z=\right.$ unknown) where two $\mathrm{L}$ 's are $\mathrm{CN}^{-}$and the third $\mathrm{L}$ is a $\mu$-thiolate of a $[4 \mathrm{Fe}-4 \mathrm{~S}]$ cluster (Figure 1). ${ }^{3,4}$ Relevant to developing active site

\footnotetext{
* To whom correspondence should be addressed. E-mail: luca.degioia@unimb.it (L.D.), rauchfuz@uiuc.edu (T.B.R.).

†University of Illinois.

\$University of Milano-Bicocca.

Supporting Information Available: X-ray crystallographic data for $\mathbf{1}(\mathrm{CO})_{4},(\mathrm{Et} 4 \mathrm{~N})\left[\mathbf{1}(\mathrm{CN})(\mathrm{CO})_{3}\right]$, and $\mathbf{1}(\mathrm{CO})_{3}(\mathrm{PMe} 3)$, details for DFT calculations, graphs for kinetics, and determination of the activation parameters. This material is available free of charge via the Internet at http://pubs.acs.org.
} 
mimics are, therefore, trisubstituted derivatives of diiron(I) dithiolato complexes of the type $\mathrm{Fe}_{2}(\mathrm{SR})_{2}(\mathrm{CO})_{3} \mathrm{~L}_{3}$.

A few trisubstituted and even tetrasubstituted derivatives are known for ligands of small cone angles and modest donor ability, such as $\mathrm{MeNC}$ and $\mathrm{P}(\mathrm{OMe})_{3} .6,7$ We have, however, shown that cyanide will not substitute more than two $\mathrm{CO}$ ligands, despite its modest steric demands. This finding shows that both ligand size and basicity affect the degree of substitution. ${ }^{8}$ Cyanide also has a tendency to form linear $\mathrm{M}-\mathrm{CN}-\mathrm{M}^{\prime}$ ensembles, ${ }^{9}$ and metal cyanides are susceptible to $\mathrm{N}$ protonation. Phosphine complexes, on the other hand, exhibit more versatile solubility without the complicating tendencies of cyanide. ${ }^{10}$ Tertiary phosphine ligands are well-known to form mono- and disubstituted products, $\mathrm{Fe}_{2}(\mathrm{SR})_{2}-(\mathrm{CO})_{6-\mathrm{x}}\left(\mathrm{PR}_{3}\right)_{x}(x=1,2),{ }^{11}$ but strategies leading to trisubstituted $[\mathrm{Fe}(\mathrm{I})]_{2}$ species are rare.

One approach to controlling the degree of substitution entails the use of chelating ligands, which could stabilize complexes of the type $\mathrm{Fe}_{2}(\mathrm{SR})_{2}(\mathrm{CO})_{3}(\mathrm{chel}) \mathrm{L}$. Species such as $\mathrm{Fe}_{2}(\mathrm{SR})_{2}(\mathrm{CO})_{4}\left(\right.$ diphosphine) and $\left[\mathrm{Fe}_{2}(\mathrm{SR})_{2}(\mathrm{CO})_{5}\right]_{2}$ (diphosphine) have been previously investigated. ${ }^{12,13}$ Complexes where the diphosphine chelates to a single iron center have been only lightly studied. ${ }^{13,14}$

From the following studies of chelated diiron dithiolates, we have been able to extract detailed information on several points relevant to the behavior of the active site. Of particular interest was the influence of the dithiolate on the reactivity of the diiron center with respect to substitution and oxidation.

\section{Results \\ $\mathrm{Fe}_{2}(\mathrm{SR})_{2}(\mathrm{CO})_{4}(\mathrm{dppv})$}

$\mathrm{Fe}_{2}\left(\mathrm{~S}_{2} \mathrm{C}_{2} \mathrm{H}_{4}\right)(\mathrm{CO})_{4}(\mathrm{dppv}), \mathbf{1}(\mathrm{CO})_{4}$, was prepared in $80 \%$ yield by decarbonylation of $\mathrm{Fe}_{2}\left(\mathrm{~S}_{2} \mathrm{C}_{2} \mathrm{H}_{4}\right)(\mathrm{CO})_{6}$ in the presence of cis-1,2-bis(diphenylphosphino)ethylene (dppv). The dppv ligand was chosen because of its preference for chelating to a single iron center rather than bridging between the two iron centers. ${ }^{13}$ When the reaction was monitored by IR spectroscopy, we observed no intermediates. Similarly, we prepared the 1,3-propanedithiolate (pdt) $\mathrm{Fe}_{2}\left(\mathrm{~S}_{2} \mathrm{C}_{3} \mathrm{H}_{6}\right)(\mathrm{CO})_{4}(\mathrm{dppv}), 2(\mathrm{CO})_{4}$, and the azadithiolate (adt) $\mathrm{Fe}_{2}\left[\left(\mathrm{SCH}_{2}\right)_{2} \mathrm{NH}\right]$ $(\mathrm{CO})_{4}(\mathrm{dppv}), \mathbf{3}(\mathrm{CO})_{4}$. All three compounds display similar IR spectroscopic features.

The IR spectrum of $\mathbf{1}(\mathrm{CO})_{4}$ features three $v_{\mathrm{CO}}$ bands, wherein the difference between the highest and lowest energy peaks, $\Delta v_{\mathrm{CO}}$, is $101 \mathrm{~cm}^{-; 1}$. DFT calculations (vide infra) suggest that the highest energy band (exptl, $2023 \mathrm{~cm}^{-1}$; theory, $2022 \mathrm{~cm}^{-1}$ ) can be approximated as the $A$ mode of the $\mathrm{Fe}(\mathrm{CO})_{3}$ subunit and that the lowest energy band (exptl, $1915 \mathrm{~cm}^{-1}$; theory, $\left.1930 \mathrm{~cm}^{-1}\right)$ is associated with the $\mathrm{Fe}-(\mathrm{dppv})(\mathrm{CO})$ subunit. For comparison, $\Delta v_{\mathrm{CO}}$ is smaller $\left(72 \mathrm{~cm}^{-; 1}\right)$ for the symmetrcially substituted species $\mathrm{Fe}_{2}\left(\mathrm{~S}_{2} \mathrm{C}_{3} \mathrm{H}_{6}\right)(\mathrm{CO})_{4}\left(\mathrm{PMePh}_{2}\right)_{2}$, whereas $\Delta v_{\mathrm{CO}}$ is $119 \mathrm{~cm}^{-;}$for the monophosphine $\mathrm{Fe}_{2}\left(\mathrm{~S}_{2} \mathrm{C}_{3} \mathrm{H}_{6}\right)(\mathrm{CO})_{5}\left(\mathrm{PMe}_{2} \mathrm{Ph}\right) .11$ The large value of $\Delta v_{\mathrm{CO}}$ for $\mathbf{1}(\mathrm{CO})_{4}$ is consistent with a structure wherein dppv is chelated to a single iron center, and the high $\Delta v_{\mathrm{CO}}$ value indicates that the second iron center should be susceptible to substitution. 15

The geometry adopted by the dppv ligand (axial-basal versus dibasal) is influenced by the nature of the chelating dithiolate. For $\mathbf{1}(\mathrm{CO})_{4}$, the ${ }^{31} \mathrm{P}$ NMR spectrum displays a single resonance at $\delta 97.4$ at $20^{\circ} \mathrm{C}$. Upon cooling of the sample to $-60^{\circ} \mathrm{C}$, this peak splits into doublets at $\delta 97.2$ and $99.5\left(J_{\mathrm{P}-\mathrm{P}}=16 \mathrm{~Hz}\right)$, indicative of an axial-basal isomer. ${ }^{10}$ This species was further characterized crystallographically (Figure 2). 
For the pdt and adt complexes, the ${ }^{31} \mathrm{P}$ NMR spectrum again consists of a singlet at $20{ }^{\circ} \mathrm{C}$, but upon cooling of the sample to $-60{ }^{\circ} \mathrm{C}$, new signals appeared, indicating the presence of four isomers. On the basis of coupling and shift patterns, we propose that two of these isomers are axial-basal and the other two isomers are dibasal. Singlets at $\delta 85.7$ and 81.6 are attributed to a pair of dibasal isomers that differ with respect to the position of the nitrogen atom of the $\left(\mathrm{SCH}_{2}\right)_{2} \mathrm{NH}$ ligand (Scheme 1 and Figure 3$)$. A pair of partially resolved AB quartets $(\delta 100.3$ and 95.0) is assigned to axial-basal isomers that again differ with respect to the orientation of the amine in $\left(\mathrm{SCH}_{2}\right)_{2} \mathrm{NH}$. A related pattern is observed for $2(\mathrm{CO})_{4}$, except that the dibasal isomers are more favored. At $-80{ }^{\circ} \mathrm{C}$, the dibasal isomer represents $18 \%$ abundance for the $\mathrm{S}_{2} \mathrm{C}_{3} \mathrm{H}_{6}$ derivative but only $8 \%$ abundance for the adt derivative. Thus, the central $\mathrm{CH}_{2}$ group of the pdt more strongly affects the orientation of the dppv ligand than does the $\mathrm{NH}$ of the adt. In general, we find that the ${ }^{31} \mathrm{P}$ NMR shifts for the dppv ligand in $\left[\mathrm{Fe}^{\mathrm{I}}\right]_{2}$ species correlate with stereochemistry: dppv ligands bound in the axial-basal fashion absorb at $>\delta 90$, whereas dppv ligands bound in the dibasal geometry absorb at $<\delta 90$.

\section{DFT Calculations on $\mathrm{Fe}_{2}(\mathrm{SR})_{2}(\mathrm{CO})_{4}(\mathrm{dppv})$}

Using DFT calculations, we probed the stereochemistry of the dppv ligand for the three dithiolato complexes. For the 1,2-ethanedithiolate (edt) derivative $\mathbf{1}(\mathrm{CO})_{4}$, computed structural parameters agree with experimental data. In particular, the discrepancy among computed and crystallographically determined bond distances is $<0.05 \AA$. Similarly, only small deviations are observed for bond angles (not shown). Calculations are in good agreement with the experimental observation that the most stable isomer is axial-basal. In the axial-basal isomer, the dppv ligand does not clash with the edt or the carbonyl ligands on the second iron center. In contrast, the dibasal isomer would induce unfavorable steric crowding between the phenyl rings and the basal carbonyl ligands on the second iron center (Figure 4). The calculated values for $v_{\mathrm{CO}}\left(2022.3,1969.9,1951.3\right.$, and $\left.1930.3 \mathrm{~cm}^{-; 1}\right)$ compare favorably with the observed spectrum $\left(2023,1953(\mathrm{br})\right.$, and $\left.1915 \mathrm{~cm}^{-1}\right)$, where the middle band consists of two overlapping vibrational frequencies.

Relative to the edt derivative, adt destabilizes the axial-basal isomers (Figure 5). In one axialbasal isomer, the $\mathrm{NH}$ group is oriented toward the $\mathrm{Fe}(\mathrm{dppv})(\mathrm{CO})$ center and experiences steric crowding with one phenyl group. An attractive interaction between the polar $\mathrm{N}-\mathrm{H}^{\delta+}$ and the $\pi$. system of the phenyl ring partially counterbalances steric problems. In the other axial-basal isomer, the $\mathrm{NH}$ group of adt points toward the axial $\mathrm{CO}$ on the $\mathrm{Fe}(\mathrm{CO})_{3}$ center. Even in this case, however, the $\mathrm{CH}_{2}$ groups of adt clash with the phenyl group of dppv. In all four conformers of $\mathrm{Fe}_{2}\left[\left(\mathrm{SCH}_{2}\right)_{2}-\mathrm{NH}\right](\mathrm{CO})_{4}(\mathrm{dppv})$, the $\mathrm{N}-H$ is axial because of the anomeric effect, in agreement with previous DFT studies. ${ }^{16}$ For the pdt derivative, $2(\mathrm{CO})_{4}$, the trimethylene group destabilizes the axial-basal isomer relative to the edt derivative because of steric clashes with one phenyl ring. In the most stable axial-basal isomer, the central $\mathrm{CH}_{2}$ of the pdt strap points away from the phenyl group (see the Supporting Information), whereas the axial-basal isomer in which the central $\mathrm{CH}_{2}$ points to the phenyl group (not shown) is less stable by 0.75 $\mathrm{kcal} / \mathrm{mol}$.

\section{Substituted Derivatives of $1(\mathrm{CO})_{4}$}

We found that $\mathbf{1}(\mathrm{CO})_{4}$ reacted efficiently with $\mathrm{PMe}_{3}$ to give $\mathrm{Fe}_{2}\left(\mathrm{~S}_{2} \mathrm{C}_{2} \mathrm{H}_{4}\right)(\mathrm{CO})_{3}(\mathrm{dppv})$ $\left(\mathrm{PMe}_{3}\right), \mathbf{1}(\mathrm{CO})_{3}\left(\mathrm{PMe}_{3}\right)$. Further substitution was not observed even with a 5 -fold excess of $\mathrm{PMe}_{3}$. The compound $\mathbf{1}(\mathrm{CO})_{4}$ also reacted efficiently with $\mathrm{Et}_{4} \mathrm{NCN}$ to give $\mathrm{Et}_{4} \mathrm{~N}-[\mathbf{1}(\mathrm{CN})$ $\left.(\mathrm{CO})_{3}\right]$ (eq 1). The structures of $\mathbf{1}(\mathrm{CO})_{3}\left(\mathrm{PMe}_{3}\right)$ and $\mathrm{Et}_{4} \mathrm{~N}\left[\mathbf{1}(\mathrm{CN})(\mathrm{CO})_{3}\right]$ were confirmed crystallographically (Figure 6). 

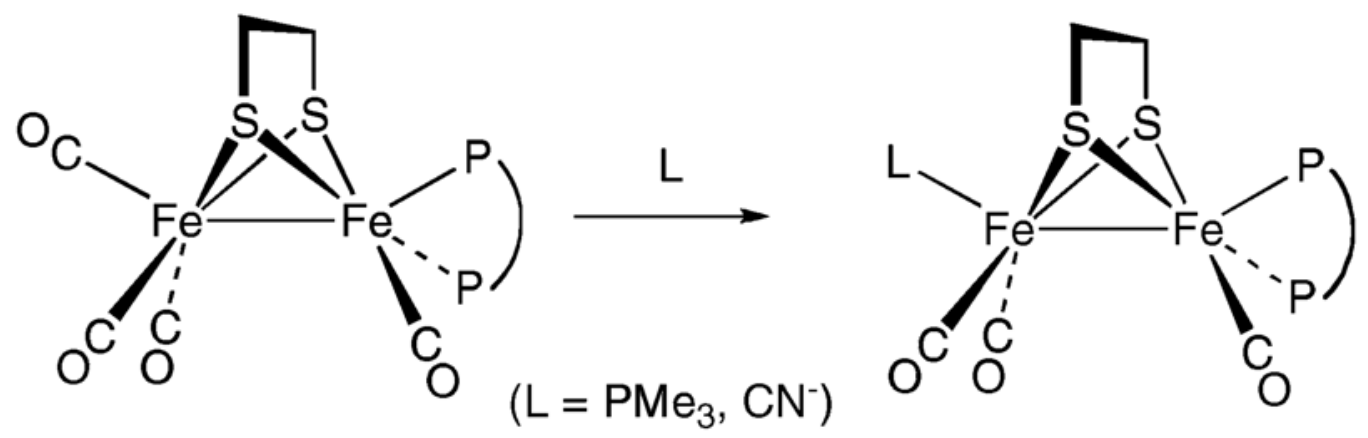

The ${ }^{31} \mathrm{P}$ NMR spectrum of $\mathbf{1}(\mathrm{CO})_{3}\left(\mathrm{PMe}_{3}\right)$ consists of singlets at $\delta 94.7$ and 20.6 at room temperature, assigned to dppv and $\mathrm{PMe}_{3}$, respectively. Upon cooling of the sample to $-90{ }^{\circ} \mathrm{C}$, these peaks split to give two sets of three signals each, indicative of two isomers in an approximately $2: 1$ ratio. On the basis of peak positions, the dppv ligand is assigned to the axialbasal orientation in both isomers. Thus, the isomers differ with respect to the axial versus basal positions of the $\mathrm{PMe}_{3}$.

\section{Kinetics of the Formation of $\mathrm{Fe}_{2}\left(\mathrm{~S}_{2} \mathrm{C}_{2} \mathrm{H}_{4}\right)(\mathrm{CO})_{3}(\mathrm{dppv})\left(\mathrm{PMe}_{3}\right)$}

To our surprise, $\mathbf{1}(\mathrm{CO})_{4}$ was found to react with $\mathrm{PMe}_{3}$ faster than the parent compound $\mathrm{Fe}_{2}\left(\mathrm{~S}_{2} \mathrm{C}_{2} \mathrm{H}_{4}\right)(\mathrm{CO})_{6}$. In a competition experiment, a solution containing a 1:1 mixture of $\mathrm{Fe}_{2}\left(\mathrm{~S}_{2} \mathrm{C}_{2} \mathrm{H}_{4}\right)(\mathrm{CO})_{6}$ and $\mathbf{1}(\mathrm{CO})_{4}$ was treated with 3 equiv of $\mathrm{PMe}_{3}$. Interestingly, $\mathbf{1}(\mathrm{CO})_{4}$ was consumed exclusively. The result is remarkable because not only is the hexacarbonyl less encumbered sterically but its effective concentration is twice that of $\mathbf{1}(\mathrm{CO})_{4}$ because it has two equivalent $\mathrm{Fe}(\mathrm{CO})_{3}$ centers. We verified that the reaction of $\mathbf{1}(\mathrm{CO})_{4}$ and $\mathrm{PMe}_{3}$ indeed proceeded via the expected bimolecular pathway. 17,18 The rate of the $1(\mathrm{CO})_{4}+\mathrm{PMe}_{3}$ reaction was examined under pseudo-first-order conditions over the temperature range 0 to $30^{\circ} \mathrm{C}$. Illustrative spectra for this conversion are presented in Figure 7. The temperature dependence of the rate indicated $\Delta H^{\ddagger}=5.8(5) \mathrm{kcal} / \mathrm{mol}$ and $\Delta S^{\ddagger}=-48(2) \mathrm{cal} / \mathrm{deg} \cdot \mathrm{mol}$. These values lead to a $\Delta G^{\ddagger}$ that is smaller than that of previously reported reactions of $\mathrm{Fe}_{2}(\mathrm{SR})_{2}(\mathrm{CO})_{6}$ with tertiary phosphines. ${ }^{17,19}$ Upon a change of the dithiolate from edt to pdt, the rate of substitution decreased approximately 5 -fold.

\section{DFT Analysis of the Substitution Process}

As a complement to the experimental results, we employed DFT to examine the reactivity of $\mathbf{1}(\mathrm{CO})_{4}$ and $\mathrm{Fe}_{2}\left(\mathrm{~S}_{2} \mathrm{C}_{2} \mathrm{H}_{4}\right)(\mathrm{CO})_{6}$. As a model nucleophile, we chose $\mathrm{KCN}$ to allow comparison with data previously obtained for related complexes. ${ }^{20}$ Energy barriers for the reactions $\mathrm{KCN}$ $+\mathbf{1}(\mathrm{CO})_{4}$ and $\mathrm{KCN}+\mathrm{Fe}_{2}-\left(\mathrm{S}_{2} \mathrm{C}_{2} \mathrm{H}_{4}\right)(\mathrm{CO})_{6}$ were calculated to be 8.4 and $13.3 \mathrm{kcal} / \mathrm{mol}$, respectively. A similar trend was observed with $\mathrm{PMe}_{3}$ as the nucleophile, with energy barriers $=10.3$ and $14.8 \mathrm{kcal} / \mathrm{mol}$ for $\mathbf{1}(\mathrm{CO})_{4}$ and $\mathrm{Fe}_{2}\left(\mathrm{~S}_{2} \mathrm{C}_{2} \mathrm{H}_{4}\right)(\mathrm{CO})_{6}$, respectively. ${ }^{21}$

The electron-rich character of the $\mathrm{Fe}(\mathrm{CO})(\mathrm{dppv})$ center induces rotation of the $\mathrm{Fe}(\mathrm{CO})_{3}$ group, favoring the formation of a $\mu$-CO structure in the transition state. The (dppv)(OC)-Fe- $\mu-C O$ distance in the transition state is calculated as $2.020 \AA$. In contrast, the $(\mathrm{OC})_{3} \mathrm{Fe}-\mu$-CO distance in the $\mathrm{Fe}_{2}\left(\mathrm{~S}_{2} \mathrm{C}_{2} \mathrm{H}_{4}\right)(\mathrm{CO})_{6}$ transition state is as long as $2.190 \AA$. The "rotated" structure is more susceptible to attack by nucleophiles than is the ground-state rotamer (Figure 8). ${ }^{20}$

\section{Diferrous Derivatives $\left[\mathrm{Fe}_{2}\left(\mathrm{~S}_{2} \mathrm{C}_{2} \mathrm{H}_{4}\right)(\mu-\mathrm{CO})(\mathrm{CO})_{2}(\mathrm{dppv}) \mathrm{L}-(\mathrm{NCMe})\right]^{2+}$}

Oxidation of $\mathrm{MeCN}$ solutions of $\mathbf{1}(\mathrm{CO})_{3}\left(\mathrm{PMe}_{3}\right)$ with 2 equiv of $\mathrm{Cp}_{2} \mathrm{FePF}_{6}$ afforded the green diferrous derivative $\left[\mathrm{Fe}_{2}\left(\mathrm{~S}_{2} \mathrm{C}_{2} \mathrm{H}_{4}\right)(\mu-\mathrm{CO})(\mathrm{CO})_{2}(\mathrm{dppv})\left(\mathrm{PMe}_{3}\right)(\mathrm{NCMe})\right]-\left(\mathrm{PF}_{6}\right)_{2},[\mathbf{1}(\mu-\mathrm{CO})$ $\left.(\mathrm{CO})_{2}\left(\mathrm{PMe}_{3}\right)(\mathrm{NCMe})\right]\left(\mathrm{PF}_{6}\right)_{2}$. The IR spectrum exhibited a band at $1909 \mathrm{~cm}^{-1}$, assigned to 
$v_{\mu-\mathrm{CO}}$. Other diferrous carbonyls exhibit $v_{\mu-\mathrm{CO}}$ bands of comparable high frequency. 22,23 The ${ }^{31} \mathrm{P}$ NMR data $\left(\delta 74.6\right.$ for the dppv and $\delta 36.4$ for the $\mathrm{PMe}_{3}$ ) indicate a $C_{s^{-}}$-symmetric species, which requires that the $\mathrm{PMe}_{3}$ is axial and the dppv is dibasal (eq 2).

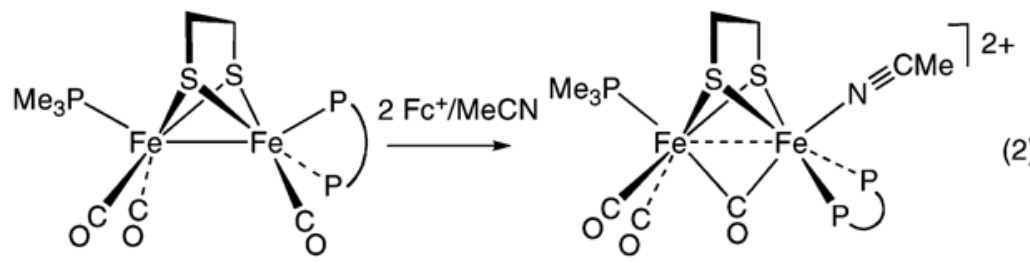

Compound $\mathbf{1}(\mathrm{CO})_{3}\left(\mathrm{PMe}_{3}\right)$ also smoothly oxidized with 2 equiv of $\mathrm{Cp}_{2} \mathrm{FePF}_{6}$ in an acetone solution at $-40{ }^{\circ} \mathrm{C}$. The initial product, assumed to be $\left[\mathrm{Fe}_{2}\left(\mathrm{~S}_{2} \mathrm{C}_{2} \mathrm{H}_{4}\right)(\mu-\mathrm{CO})(\mathrm{CO})_{2}-(\mathrm{dppv})\right.$ $\left.\left(\mathrm{PMe}_{3}\right)\left(\mathrm{OCMe}_{2}\right)\right]^{2+}$, was identified by FT-IR spectroscopy. The $v_{\mathrm{CO}}$ portion of the spectrum $\left(2059,2015\right.$, and $\left.1912 \mathrm{~cm}^{-1}\right)$ is quite similar in pattern and energy to that seen for the $\mathrm{MeCN}$ adduct. The stabilities of the MeCN and acetone complexes, however differ sharply: the acetone complex decomposes upon warming of the reaction solution to room temperature, while the MeCN complex is stable both as a solid and in solution at room temperature for extended periods.

Complex $\left[\mathbf{1}(\mu-\mathrm{CO})(\mathrm{CO})_{2}\left(\mathrm{PMe}_{3}\right)(\mathrm{NCMe})\right]^{2+}$ is reactive toward further substitution, in contrast to the parent $1(\mathrm{CO})_{3}-\left(\mathrm{PMe}_{3}\right)$. The addition of 1 equiv of $\mathrm{PMe}_{3}$ to a solution of $[1(\mu-\mathrm{CO})$ $\left.(\mathrm{CO})_{2}\left(\mathrm{PMe}_{3}\right)(\mathrm{NCMe})\right]\left(\mathrm{PF}_{6}\right)_{2}$ caused a color change from green to red. New $v_{\mathrm{CO}}$ peaks appeared at 1983 and $1888 \mathrm{~cm}^{-1}$, with the former being the single terminal carbonyl and the latter the bridging carbonyl peak. On the basis of ${ }^{1} \mathrm{H}$ and ${ }^{31} \mathrm{P}$ NMR and IR spectroscopies and electrospray ionization mass spectrometry (ESI-MS), the new compound was identified as [1 $(\mu-\mathrm{CO})(\mathrm{CO})\left(\mathrm{PMe}_{3}\right)_{2}(\mathrm{NCMe})\left(\mathrm{PF}_{6}\right)_{2}(\mathrm{eq} 3)$. The ${ }^{31} \mathrm{P}$ NMR spectrum indicates that the dppv is dibasal and that the complex lacks symmetry. This species is similar to the recently described $\left[\mathrm{Fe}_{2}\left(\mathrm{~S}_{2} \mathrm{C}_{2} \mathrm{H}_{4}\right)(\mu-\mathrm{CO})(\mathrm{CO})\left(\mathrm{PMe}_{3}\right)_{4}-(\mathrm{NCMe})\right]\left(\mathrm{PF}_{6}\right)_{2} \cdot{ }^{10}$ Spectroscopic evidence suggests that oxidation of $\mathrm{Et}_{4} \mathrm{~N}\left[\mathbf{1}(\mathrm{CN})(\mathrm{CO})_{3}\right]$ with 2 equiv of $\mathrm{Cp}_{2} \mathrm{FePF}_{6}$ resulted in the formation of $\left[\mathrm{Fe}_{2}\left(\mathrm{~S}_{2} \mathrm{C}_{2} \mathrm{H}_{4}\right)(\mu-\mathrm{CO})(\mathrm{CN})(\mathrm{CO})_{2}-(\mathrm{dppv})(\mathrm{NCMe})\right] \mathrm{PF}_{6},\left[\mathbf{1}(\mu-\mathrm{CO})(\mathrm{CN})(\mathrm{CO})_{2}(\mathrm{NCMe})\right] \mathrm{PF}_{6} . \mathrm{On}$ the basis of its ${ }^{31} \mathrm{P}$ NMR spectrum, which indicates equivalent phosphorus ligands, this species has $C_{S}$ symmetry. Consistent with this conclusion, DFT calculations on these diferrous species indicate that donor ligands will preferentially occupy sites trans to $\mu$ - $\mathrm{CO}$ (Figure 9).

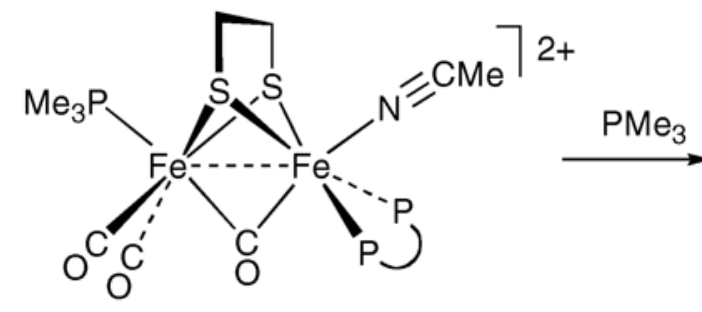

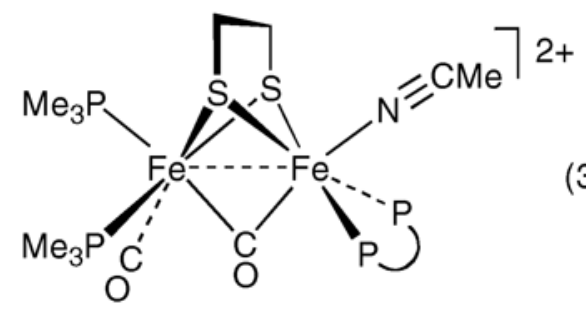




\section{Oxidations of pdt Derivatives}

To explore the $2 \mathrm{e}^{-}$oxidation of the pdt derivatives, we prepared $\mathrm{Fe}_{2}\left(\mathrm{~S}_{2} \mathrm{C}_{3} \mathrm{H}_{6}\right)-(\mathrm{CO})_{3}(\mathrm{dppv})$ $\left(\mathrm{PMe}_{3}\right), 2(\mathrm{CO})_{3}\left(\mathrm{PMe}_{3}\right)$. The preparation proceeded analogously to that for the synthesis of $\mathbf{1}$ $(\mathrm{CO})_{3}\left(\mathrm{PMe}_{3}\right)$. Low-temperature ${ }^{31} \mathrm{P}$ NMR measurements show that this species exists as three isomers. Interestingly, the dibasal isomer is far less populated in this species than in its tetracarbonyl precursor, apparently as a result of the $\mathrm{PMe}_{3}$ ligand, probably axially coordinated, pushing the dibasal $\mathrm{CO}$ ligands toward the base and inducing nonbonded interactions with the phenyl rings on the dppv.

Treatment of $2(\mathrm{CO})_{3}\left(\mathrm{PMe}_{3}\right)$ with 2 equiv of $\mathrm{Cp}_{2} \mathrm{FePF}_{6}$ at $-40{ }^{\circ} \mathrm{C}$ resulted in an immediate change in the $v_{\mathrm{CO}}$ region of the IR spectrum to a pattern resembling that for $[\mathbf{1}(\mu-\mathrm{CO})$ $\left.(\mathrm{CO})_{2}\left(\mathrm{PMe}_{3}\right)(\mathrm{NCMe})\right]^{2+}$, i.e., one bridging $\left(v_{\mu-\mathrm{CO}}=1922 \mathrm{~cm}^{-; 1}\right)$ and two terminal $\left(v_{\mathrm{CO}-\mathrm{t}}=\right.$ 2055 and $2009 \mathrm{~cm}^{-1}$ ) bands. The shift of $v_{\mathrm{CO}-\mathrm{t}}$ to higher energies is typical for the oxidation to the diferrous state, and the broad, low-intensity band is typical for $v_{\mu-\mathrm{CO}}$. The energies of these bands were, however, quite different for the pdt versus edt derivatives: the $\mu$-CO band occurs at $1921 \mathrm{~cm}^{-1}$ for the pdt derivative, $12 \mathrm{~cm}^{-1}$ higher than that for the edt derivative. This shift is compensated for by opposite shifts in $v_{\mathrm{CO}-\mathrm{t}}$, which are each ca. $7 \mathrm{~cm}^{-1}$ lower than those for the edt derivative. Thus, the data indicate that the terminal $\mathrm{CO}$ ligands are relatively better $\pi$ acceptors for the pdt derivative, whereas the $\mu$-CO ligand is relatively more of a $\pi$ acceptor in the edt derivative. The effect of the dithiolate on the stability of the oxidized derivatives is profound: whereas $\left[\mathbf{1}(\mu-\mathrm{CO})(\mathrm{CO})_{2}\left(\mathrm{PMe}_{3}\right)(\mathrm{NCMe})\right]^{2+}$ is robust at room temperature, $[2(\mu-\mathrm{CO})$ $\left.(\mathrm{CO})_{2}\left(\mathrm{PMe}_{3}\right)(\mathrm{NCMe})\right]^{2+}$ decomposed within ca. $30 \mathrm{~min}$ at $-40{ }^{\circ} \mathrm{C}$. The addition of $\mathrm{PMe}_{3}$ to a solution of $\left[2(\mu-\mathrm{CO})(\mathrm{CO})_{2}\left(\mathrm{PMe}_{3}\right)(\mathrm{NCMe})\right]^{2+}$ at $-40{ }^{\circ} \mathrm{C}$ did not yield an isolable derivative. Oxidation of the adt derivative $\mathrm{Fe}_{2}\left[\left(\mathrm{SCH}_{2}\right)_{2} \mathrm{NH}\right](\mathrm{CO})_{3}\left(\mathrm{PMe}_{3}\right)(\mathrm{dppv})$ did not yield stable or observable diferrous derivatives.

\section{Discussion}

\section{Reactivity of $\mathrm{Fe}_{2}(\mathrm{SR})_{2}(\mathrm{CO})_{4}(\mathrm{dppv})$}

Ligands substitute $\mathbf{1}(\mathrm{CO})_{4}$ exclusively at the $\mathrm{Fe}(\mathrm{CO})_{3}$ subunit under mild conditions. This reactivity enabled the preparation of otherwise rare trisubstituted diiron(I) dithiolato complexes. Kinetic studies indicate that $\mathbf{1}(\mathrm{CO})_{4}$ is more electrophilic than the parent hexacarbonyl. According to the prevailing mechanistic paradigm, ${ }^{20}$ substitution at $\mathrm{Fe}_{2}(\mathrm{SR})_{2}(\mathrm{CO})_{6-n} \mathrm{~L}_{n}$ proceeds via attack of the nucleophile on a rotamer that features an exposed coordination site on one $\mathrm{Fe}(\mathrm{CO})_{3}$ subunit, trans to the $\mathrm{Fe}-\mathrm{Fe}$ bond (Scheme 2). The binding of a ligand $\mathrm{L}$ to this "rotated isomer" ruptures the $\mathrm{Fe}-\mathrm{Fe}$ bond, forming the $36 \mathrm{e}^{-}$adduct $\mathrm{Fe}_{2}(\mathrm{SR})_{2}(\mu-\mathrm{CO})(\mathrm{CO})_{3} \mathrm{~L}_{3}$. Such $36 \mathrm{e}^{-}$adducts readily decarbonylate concomitant with reformation of the $\mathrm{Fe}-\mathrm{Fe}$ bond and subsequent rotation of the $\mathrm{Fe}(\mathrm{CO})_{2} \mathrm{~L}$ to its ground-state orientation.

Pickett et al. have spectroscopically detected an adduct of the type $\mathrm{Fe}_{2}(\mathrm{SR})_{2}(\mu$-CO) $(\mathrm{CO})_{6-x} \mathrm{~L}_{x}$ in the cyanation of $\mathrm{Fe}_{2}\left[\left(\mathrm{SCH}_{2}\right)_{2} \mathrm{C}(\mathrm{Me}) \mathrm{CH}_{2} \mathrm{SMe}\right](\mathrm{CO})_{6} \cdot{ }^{19}$ In their case, a pendent SMe ligand stabilizes the $36 \mathrm{e}^{-}$intermediate. Recent DFT calculations suggest that the "rotated" geometry is stabilized by the presence of donor ligands in unsymmetrically substituted complexes. ${ }^{24,25}$ Darensbourg and Hall calculate that unsymmetrical substitution of the diiron center stabilizes the rotated structure, thereby accelerating substitution. ${ }^{25}$ Our results support the role of the rotated structure. Our calculations agree with these previous predictions: the dppv ligand in $\mathbf{1}(\mathrm{CO})_{4}$ stabilizes the rotated transition state by about $5 \mathrm{kcal} / \mathrm{mol}$. For the reaction $\mathrm{Fe}_{2}\left(\mathrm{~S}_{2} \mathrm{C}_{2} \mathrm{H}_{4}\right)(\mathrm{CO})_{6}+\mathrm{PBu}_{3}, \Delta H^{\ddagger}=13.6 \mathrm{kcal} / \mathrm{mol}$ and $\Delta S^{\ddagger}=-31 \mathrm{cal} / \mathrm{deg} \cdot \mathrm{mol}$, whereas the presently discussed $\mathbf{1}(\mathrm{CO})_{4}+\mathrm{PMe}_{3}$ reaction proceeds with $\Delta H^{\ddagger}=5.8(5) \mathrm{kcal} / \mathrm{mol}$ and $\Delta S^{\ddagger}=$ -48 (2) cal/deg.mol. The enthalpic advantage for the dppv complexes is attributed to the 
stabilization of the rotated structure, which precedes attack by the nucleophile. We do not presently understand the characteristics of the ligands that will lead to such rate accelerations.

\section{Effect of the Dithiolate (edt vs pdt vs adt) on Subferrous Species}

A general question arising from studies on diiron dithiolato carbonyls concerns the influence of the dithiolate on the reactivity and structure of the underlying $\mathrm{Fe}_{2}(\mathrm{CO})_{6-x} \mathrm{~L}_{x}$ subunit. ${ }^{6,18}$, 22 An understanding of how the dithiolate influences the reactivity of the underlying diiron centers is relevant to the design of new dimetallic reaction centers based on dithiolato bridges.

The rate of substitution was found to depend upon the dithiolate ligand. Differences in rates must reflect differences in the steric accessibility of the axial position because the electronic properties of the $\mathrm{Fe}_{2}(\mathrm{SR})_{2}(\mathrm{CO})_{4}(\mathrm{dppv})$ cores are virtually identical, as indicated by $v_{\mathrm{CO}}$ values. The reaction of $\mathbf{1}(\mathrm{CO})_{4}$ with $\mathrm{PMe}_{3}$ was ca. 5 times faster than the corresponding reaction for the pdt derivative. This difference is attributed to increased steric protection provided by the pdt ligand, which positions its central $\mathrm{CH}_{2}$ group over the axial sites on the diiron framework.

The relative steric bulk of the dithiolates is indicated by the ratio of the dibasal versus axialbasal isomers for $\mathrm{Fe}_{2}-(\mathrm{xdt})(\mathrm{CO})_{4}(\mathrm{dppv})(\mathrm{xdt}=\mathrm{adt}$, edt, $\mathrm{pdt})$. At comparable temperatures, the ratio of axial-basal/dibasal was >20:1 (edt), 12:1 (adt), and 7:1 (pdt). Thus, pdt and adt are sterically more imposing than edt. The steric bulk of pdt versus adt does not appear to influence the barrier for the interconversion of the dibasal and axial-basal isomers. The turnstile rotation of related compounds has been well studied. ${ }^{18,26}$

\section{Impact of Dithiolate on Diferrous Species}

Previous work had shown that oxidative decarbonylation of $\mathrm{Fe}_{2}(\mathrm{SR})_{2}-(\mathrm{CO})_{6-x} \mathrm{~L}_{x}\left(\mathrm{~L}=\mathrm{PR}_{3}\right.$, $\mathrm{RNC}$ ) gives diferrous derivatives. ${ }^{22,23}$ In general, larger ligands $\left(\mathrm{PMe}_{3}\right)$ are not tolerated for pdt derivatives; thus, nature's use of small ligands $\left(\mathrm{CO}\right.$ and $\left.\mathrm{CN}^{-}\right)$on the "distal" iron (location of the variable coordination site) is understandable. Consistent with this view, the nature of the dithiolate strap was found to strongly affect the stability of the derivatives in the series $\left[\mathrm{Fe}_{2}(\mathrm{xdt})(\mu-\mathrm{CO})(\mathrm{CO})_{2}-(\mathrm{dppv})\left(\mathrm{PMe}_{3}\right)(\mathrm{NCMe})\right]^{2+}[\mathrm{xdt}=\mathrm{edt}$, adt, pdt]. The edt species was robust at room temperature, the pdt derivative was observable at low temperature, and the adt derivative could not be generated. Because adt is less bulky than pdt, the instability of this oxidized compound indicates that a combination of steric and electronic effects are relevant.

We had previously shown that $\mathrm{Fe}_{2}\left(\mathrm{~S}_{2} \mathrm{C}_{2} \mathrm{H}_{4}\right)(\mathrm{CO})_{4}\left(\mathrm{PMe}_{3}\right)_{2}$ could be oxidized to give derivatives $\left[\mathrm{Fe}^{\mathrm{II}}{ }_{2}\left(\mathrm{~S}_{2} \mathrm{C}_{2} \mathrm{H}_{4}\right)(\mu-\mathrm{CO})-(\mathrm{CO})_{2}\left(\mathrm{PMe}_{3}\right)_{3}(\mathrm{NCMe})\right]^{2+}$ and $\left[\mathrm{Fe}_{2}{ }_{2}\left(\mathrm{~S}_{2} \mathrm{C}_{2} \mathrm{H}_{4}\right)(\mu-\mathrm{CO})-\right.$ $\left.\left(\mathrm{PMe}_{3}\right) 4(\mathrm{NCMe})\right]^{2+}$. These reactions require the addition of trapping donor ligands such as $\mathrm{PMe}_{3}$, which displace one or two terminal CO ligands, stabilizing the higher oxidation state. Being already trisubstituted, $\mathrm{Fe}_{2}(\mathrm{SR})_{2}(\mathrm{CO})_{3}(\mathrm{dppv}) \mathrm{L}$ underwent efficient oxidation without the need for exogenous donor ligands (aside from the $\mathrm{MeCN}$ provided by the solvent). Oxidation proceeded in acetone, but the adduct was thermally unstable. In the diferrous state of the enzyme, the so-called $\mathrm{H}_{\mathrm{ox}}$ air , an axial site is proposed to be occupied by water, which we propose is simulated by $\mathrm{MeCN}$ in our case. In this and related work, we have not observed coordination of water.

\section{Conclusions}

Studies on diiron dithiolato complexes with unsymmetrical coordination environments have led to a better understanding of the influence of the dithiolate on the stereochemistry of these complexes. The unsymmetrical coordination environment enhances the overall reactivity of the subferrous complexes, allowing a third ligand to be easily installed. Trisubstituted 
complexes undergo oxidation to the diferrous derivatives under highly controlled conditions, providing the foundation for future detailed studies on the redox properties of diiron dithiolates.

\section{Experimental Section}

Unless otherwise indicated, reactions were conducted using Schlenk techniques at room temperature. Chemicals were purchased from Aldrich, and solvents were either HPLC-grade from an alumina filtration system or distilled under nitrogen over an appropriate drying agent. NMR spectra were recorded at room temperature on a Varian Mercury $500 \mathrm{MHz}$ spectrometer. NMR chemical shifts are quoted in ppm; spectra are referenced to tetramethylsilane for ${ }^{1} \mathrm{H}$ and ${ }^{13} \mathrm{C}\left\{{ }^{1} \mathrm{H}\right\}$ NMR and $85 \% \mathrm{H}_{3} \mathrm{PO}_{4}$ for ${ }^{31} \mathrm{P}\left\{{ }^{1} \mathrm{H}\right\}$ NMR spectra. FTIR spectra were recorded on a Mattson Infinity Gold FTIR spectrometer. $\mathrm{Fe}_{2}\left(\mathrm{~S}_{2} \mathrm{C}_{2} \mathrm{H}_{4}\right)(\mathrm{CO})_{6}, \mathrm{Fe}_{2}\left(\mathrm{~S}_{2} \mathrm{C}_{3} \mathrm{H}_{6}\right)-(\mathrm{CO}) 6$, and $\mathrm{Fe}_{2}\left[\left(\mathrm{SCH}_{2}\right) 2 \mathrm{NH}\right](\mathrm{CO})_{6}{ }^{27}$ were prepared according to literature procedures. PMe3 was distilled prior to use on a high-vacuum line. Et4NCN and dppv were obtained from Aldrich. $\mathrm{ONMe} 3$ was obtained from Aldrich and dried by repeated vacuum sublimation.

\section{$\mathrm{Fe}_{2}\left(\mathrm{~S}_{2} \mathrm{C}_{2} \mathrm{H}_{4}\right)(\mathrm{CO})_{4}(\mathrm{dppv}), 1(\mathrm{CO})_{4}$}

A solution of $2.70 \mathrm{~g}(7.24 \mathrm{mmol})$ of $\mathrm{Fe}_{2}\left(\mathrm{~S}_{2} \mathrm{C}_{2} \mathrm{H}_{4}\right)(\mathrm{CO})_{6}$ in $35 \mathrm{~mL}$ of toluene was treated with a solution of $0.54 \mathrm{~g}(7.24 \mathrm{mmol})$ of $\mathrm{Me}_{3} \mathrm{NO}$ in $15 \mathrm{~mL}$ of MeCN. After stirring for $10 \mathrm{~min}$, the reaction mixture was treated with a solution of $2.87 \mathrm{~g}(7.24 \mathrm{mmol})$ of dppv in $20 \mathrm{~mL}$ of toluene. After $5 \mathrm{~h}$, the solvent was removed in vacuum. The residue, a brown solid, was extracted into $10 \mathrm{~mL}$ of $\mathrm{CH}_{2} \mathrm{Cl}_{2}$, and the product precipitated as a light-brown powder upon the addition of $100 \mathrm{~mL}$ of hexanes. The product was rinsed with $\sim 60 \mathrm{~mL}$ of hexanes. Crystals were grown via slow evaporation of a MeCN-toluene solution. Yield: $4.57 \mathrm{~g}(82 \%) .{ }^{1} \mathrm{H} \mathrm{NMR}\left(\mathrm{CD}_{2} \mathrm{Cl}_{2}\right): \delta$ 7.7-7.1 (m, 20H, $\left.\mathrm{C}_{6} \mathrm{H}_{5}\right), 4.3(\mathrm{~s}, 2 \mathrm{H}, \mathrm{PCH}), 1.6\left(\mathrm{~m}, 2 \mathrm{H}, \mathrm{SCH}_{2}\right), 1.1\left(\mathrm{~m}, 2 \mathrm{H}, \mathrm{SCH}_{2}\right) .{ }^{31} \mathrm{P} \mathrm{NMR}$ $\left(\mathrm{CD}_{2} \mathrm{Cl}_{2}\right): \delta 97.4$ at $20{ }^{\circ} \mathrm{C} ; 99.5\left(\mathrm{~d}, J_{\mathrm{P}-\mathrm{P}}=16 \mathrm{~Hz}\right), 97.2\left(\mathrm{~d}, J_{\mathrm{P}-\mathrm{P}}=16 \mathrm{~Hz}\right)$ at $-60{ }^{\circ} \mathrm{C}$. IR $\left(\mathrm{CH}_{2} \mathrm{Cl}_{2}\right): v_{\mathrm{CO}} 2023,1953,1915 \mathrm{~cm}^{-1}$. FD-MS: $\mathrm{m} / z$ 712.02 (1(CO) $\left.)_{4}\right)$. Anal. Calcd for $\mathrm{C}_{32} \mathrm{H}_{26} \mathrm{Fe}_{2} \mathrm{O}_{4} \mathrm{P}_{2} \mathrm{~S}_{2}$ (found): $\mathrm{C}, 53.94$ (53.73); H, 3.68 (3.63).

$\mathrm{Fe}_{2}\left(\mathrm{~S}_{2} \mathrm{C}_{3} \mathrm{H}_{6}\right)(\mathrm{CO})_{4}(\mathrm{dppv}), 2(\mathrm{CO})_{4}$, was prepared similarly. Yield: 57\%. ${ }^{1} \mathrm{H}$ NMR $\left(\mathrm{CD}_{2} \mathrm{Cl}_{2}\right)$ : $\delta 7.7-7.1\left(\mathrm{~m}, 20 \mathrm{H}, \mathrm{C}_{6} H_{5}\right), 4.3(\mathrm{~s}, 2 \mathrm{H}, \mathrm{PCH}), 1.59\left(\mathrm{~m}, 4 \mathrm{H}, \mathrm{SCH}_{2}\right), 1.29\left(\mathrm{~m}, 2 \mathrm{H}, \mathrm{SCH}_{2}\right), 0.97$ $\left(\mathrm{m}, 2 \mathrm{H}, \mathrm{CH}_{2} \mathrm{CH}_{2} \mathrm{CH}_{2}\right) .{ }^{31} \mathrm{P}$ NMR $\left(\mathrm{CD}_{2} \mathrm{Cl}_{2}\right): \delta 96.9,82.9$ at $20{ }^{\circ} \mathrm{C} ; 95.9$ at $90{ }^{\circ} \mathrm{C} ; 103.2,100.0$, 96.0, 95.5, 85.7, 82.3 at $-90{ }^{\circ} \mathrm{C}$. IR $\left(\mathrm{CH}_{2}-\mathrm{Cl}_{2}\right): v_{\mathrm{CO}} 2021,1950,1912 \mathrm{~cm}^{-1}$. FD-MS: $\mathrm{m} / \mathrm{z} 726.5$ (2(CO) $)_{4}$ ). Anal. Calcd for $\mathrm{C}_{33} \mathrm{H}_{28} \mathrm{Fe}_{2} \mathrm{O}_{4} \mathrm{P}_{2} \mathrm{~S}_{2}$ (found): C, 54.55 (54.60); H, 3.89 (3.87).

$\mathrm{Fe}_{2}\left(\mathrm{~S}_{2}\left(\mathrm{CH}_{2}\right)_{2} \mathrm{NH}\right)(\mathrm{CO})_{4}(\mathrm{dppv}), \mathbf{3}(\mathrm{CO})_{4}$, was prepared similarly. Yield: $26 \%$. ${ }^{1} \mathrm{H}$ NMR (toluene- $\left.d_{8}\right): \delta 7.7-7.1\left(\mathrm{~m}, 20 \mathrm{H}, \mathrm{C}_{6} H_{5}\right), 4.3(\mathrm{~s}, 2 \mathrm{H}, \mathrm{PCH}), 3.04\left(\mathrm{~m}, 4 \mathrm{H}, \mathrm{SCH}_{2} \mathrm{~N}\right) .{ }^{31} \mathrm{P}$ NMR $\left(\mathrm{CD}_{2} \mathrm{Cl}_{2}, 20{ }^{\circ} \mathrm{C}\right): \delta$ 97.6. ${ }^{31} \mathrm{P}$ NMR $\left(\mathrm{CD}_{2} \mathrm{Cl}_{2},-60{ }^{\circ} \mathrm{C}\right): \delta 101.4,100.7\left(J_{\mathrm{P}-\mathrm{P}}=20 \mathrm{~Hz}\right), 97.2$, $95.3\left(J_{\mathrm{P}-\mathrm{P}}=20 \mathrm{~Hz}\right), 86.0,82.9$. IR $\left(\mathrm{CH}_{2} \mathrm{Cl}_{2}\right): v_{\mathrm{CO}} 2021,1953,1915 \mathrm{~cm}^{-1}$. FD-MS: $m / z 727.0$ $\left(3(\mathrm{CO})_{4}\right)$.

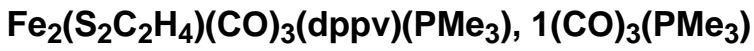

A solution of $0.30 \mathrm{~g}(0.421 \mathrm{mmol})$ of $\mathbf{1}(\mathrm{CO})_{4}$ in $20 \mathrm{~mL}$ of toluene was treated with a solution of $0.031 \mathrm{~g}(0.421 \mathrm{mmol})$ of $\mathrm{Me}_{3} \mathrm{NO}$ in $5 \mathrm{~mL}$ of $\mathrm{MeCN}$. To this solution was added $0.90 \mathrm{~mL}$ $(0.450 \mathrm{mmol})$ of a $0.50 \mathrm{M}$ solution of $\mathrm{PMe}_{3}$ in toluene. After $12 \mathrm{~h}$, the solvent was removed in vacuum. The dark-red residue was extracted into $5 \mathrm{~mL}$ of $\mathrm{CH}_{2} \mathrm{Cl}_{2}$, and the product was precipitated as a dark-red powder upon the addition of $50 \mathrm{~mL}$ of hexanes. Crystals were grown via slow diffusion of hexanes into a $\mathrm{CH}_{2} \mathrm{Cl}_{2}$ solution. Yield: $0.28 \mathrm{~g} \mathrm{(88 \% ).}{ }^{1} \mathrm{H} \mathrm{NMR}$ $\left.\left(\mathrm{CD}_{2} \mathrm{Cl}_{2}\right): \delta 8.0-7.2\left(\mathrm{~m}, 20 \mathrm{H}, \mathrm{C}_{6} H_{5}\right), 4.3(\mathrm{~s}, 2 \mathrm{H}, \mathrm{PCH}), 1.6(\mathrm{~m}, 2 \mathrm{H}, \mathrm{SCH})_{2}\right) 1.2\left(\mathrm{~d}, J_{\mathrm{P}-\mathrm{H}}=8\right.$ $\left.\mathrm{Hz}, 9 \mathrm{H}, \mathrm{PCH} \mathrm{H}_{3}\right), 0.8\left(\mathrm{~m}, 2 \mathrm{H}, \mathrm{SCH}_{2}\right) .{ }^{31} \mathrm{P} \mathrm{NMR}\left(\mathrm{CD}_{2} \mathrm{Cl}_{2}, 20{ }^{\circ} \mathrm{C}\right): \delta 94.7,20.6 .{ }^{31} \mathrm{P}$ NMR $\left(\mathrm{CD}_{2} \mathrm{Cl}_{2},-90^{\circ} \mathrm{C}\right): \delta 101.1,96.3,94.0,92.7,28.4,11.5$. IR $\left(\mathrm{CH}_{2}-\mathrm{Cl}_{2}\right): v_{\mathrm{CO}} 1943,1892 \mathrm{~cm}^{-1}$. 
FD-MS: $m / z 760.00\left(\left[\mathrm{Fe}_{2}\left(\mathrm{~S}_{2} \mathrm{C}_{2} \mathrm{H}_{4}\right)-(\mathrm{CO})_{3}(\mathrm{dppv})\left(\mathrm{PMe}_{3}\right)\right]\right)$. Anal. Calcd for

$\mathrm{C}_{34} \mathrm{H}_{35} \mathrm{Fe}_{2} \mathrm{O}_{3} \mathrm{P}_{3} \mathrm{~S}_{2}$ (found): $\mathrm{C}, 53.68$ (53.82); H, 4.64 (4.51).

\section{Reaction of $\mathrm{Fe}_{2}\left(\mathrm{~S}_{2} \mathrm{C}_{2} \mathrm{H}_{4}\right)(\mathrm{CO})_{6}$ and $1(\mathrm{CO})_{4}$ with $\mathrm{PMe}_{3}$}

A solution of $0.050 \mathrm{~g}(0.134 \mathrm{mmol})$ of $\mathrm{Fe}_{2}\left(\mathrm{~S}_{2} \mathrm{C}_{2} \mathrm{H}_{4}\right)(\mathrm{CO})_{6}$ and $0.096 \mathrm{~g}(0.134 \mathrm{mmol})$ of 1 $(\mathrm{CO})_{4}$ in $10 \mathrm{~mL}$ of toluene was treated with $0.41 \mathrm{~mL}(0.402 \mathrm{mmol})$ of a $0.98 \mathrm{M}$ solution of $\mathrm{PMe}_{3}$ in toluene. After $1 \mathrm{~h}$, the following IR spectrum was obtained: $v_{\mathrm{CO}} 2075,2035,2002$, and $1991 \mathrm{~cm}^{-1}$ for $\mathrm{Fe}_{2}\left(\mathrm{~S}_{2} \mathrm{C}_{2} \mathrm{H}_{4}\right)(\mathrm{CO})_{6}$ and $v_{\mathrm{CO}} 1960,1949,1911$, and $1895 \mathrm{~cm}^{-1}$ for $\mathbf{1}$ $(\mathrm{CO})_{3}\left(\mathrm{PMe}_{3}\right)$.

\section{$\mathrm{Et}_{4} \mathrm{~N}\left[\mathrm{Fe}_{2}\left(\mathrm{~S}_{2} \mathrm{C}_{2} \mathrm{H}_{4}\right)(\mathrm{CN})(\mathrm{CO})_{3}(\mathrm{dppv})\right], \mathrm{Et}_{\mathbf{4}} \mathrm{N}\left[1(\mathrm{CN})(\mathrm{CO})_{3}\right]$}

A solution of $0.750 \mathrm{~g}(1.03 \mathrm{mmol})$ of $\mathbf{1}(\mathrm{CO})_{4}$ in $15 \mathrm{~mL}$ of $\mathrm{MeCN}$ was treated with a solution of $0.161 \mathrm{~g}(1.03 \mathrm{mmol})$ of $\mathrm{Et}_{4} \mathrm{NCN}$ in $10 \mathrm{~mL}$ of $\mathrm{MeCN}$. The solution was stirred for $3 \mathrm{~h}$ and the solvent removed in vacuum. The residue, a dark-red solid, was recrystallized by extraction into $5 \mathrm{~mL}$ of $\mathrm{CH}_{2} \mathrm{Cl}_{2}$, followed by the addition of $50 \mathrm{~mL}$ of hexanes. Crystals were grown via slow diffusion of hexanes into a $\mathrm{CH}_{2} \mathrm{Cl}_{2}$ solution. Yield: $0.65 \mathrm{~g}(75 \%)$. ${ }^{1} \mathrm{H} \mathrm{NMR}\left(\mathrm{MeCN}-\mathrm{d}_{3}\right)$ : $\delta 8.1-7.2\left(\mathrm{~m}, 20 \mathrm{H}, \mathrm{C}_{6} \mathrm{H}_{5}\right), 5.4(\mathrm{~s}, 2 \mathrm{H}, \mathrm{PCH}), 3.5\left(\mathrm{q}, 16 \mathrm{H}, \mathrm{NCH}_{2} \mathrm{CH}_{3}\right), 1.6\left(\mathrm{~m}, 2 \mathrm{H}, \mathrm{SCH}_{2}\right), 1.4$ (t, $\left.24 \mathrm{H}, \mathrm{NCH}_{2} \mathrm{CH}_{3}\right), 1.2\left(\mathrm{~m}, 2 \mathrm{H}, \mathrm{SCH}_{2}\right) .{ }^{31} \mathrm{P}$ NMR (MeCN-d3, $\left.20{ }^{\circ} \mathrm{C}\right): \delta 94.7 . \mathrm{IR}(\mathrm{MeCN}):$ $v_{\mathrm{CN}} 2072 \mathrm{~cm}^{-1} ; v_{\mathrm{CO}} 1943,1890 \mathrm{~cm}^{-1}$. ESI-MS: $\mathrm{m} / z 710.30\left(\left[\mathrm{Fe}_{2}\left(\mathrm{~S}_{2} \mathrm{C}_{2} \mathrm{H}_{4}\right)(\mathrm{CN})\right.\right.$ (CO) $\left.{ }_{3}(\mathrm{dppv})\right]^{-}$). Anal. Calcd for $\mathrm{C}_{41} \mathrm{H}_{48} \mathrm{Fe}_{2} \mathrm{~N}_{2} \mathrm{O}_{3} \mathrm{P}_{2} \mathrm{~S}_{2} \mathrm{Cl}_{2}$ (found): $\mathrm{C}, 53.20$ (52.97); H, 5.06 (5.22); N, 3.06 (3.02).

\section{Kinetics}

Pseudo-first-order reaction conditions were employed for all kinetics studies, using 10 equiv or more of $\mathrm{PMe}_{3}$. Reactions were performed in a Schlenk vessel designed to contain the in situ IR probe (React IR). Typically, the reactor, a $50 \mathrm{~mL}$ flask, was charged with $0.050 \mathrm{~g}(0.070$ mmol) of 1 and flushed with $\mathrm{N}_{2}$ before the addition of $5.0 \mathrm{~mL}$ of $\mathrm{CH}_{2} \mathrm{Cl}_{2}$. The IR probe was then inserted into the $0.014 \mathrm{M}$ reaction mixture, and the reaction mixture was placed into a thermostatted bath. Following thermal equilibration, a $0.78 \mathrm{M}$ solution $\mathrm{PMe}_{3}$ in $\mathrm{CH}_{2} \mathrm{Cl}_{2}$ was injected rapidly. While being magnetically stirred, the solution was analyzed by IR spectroscopy typically at intervals of $15 \mathrm{~s}$ until the reaction was judged complete and then at $30 \mathrm{~s}$ intervals for an additional $30 \mathrm{~min}$. The rates of reaction were analyzed using the program Concert (Mettler-Toledo). Pseudo-first-order rate constants were the slopes of plots of $\ln (1$ $(\mathrm{CO})_{4}$ ) vs time (seconds). Rates were determined for the following concentrations of $\mathrm{PMe}_{3}$ : $10,20,30$, and 40 equiv at $20^{\circ} \mathrm{C}$. The slope of the graph of $k_{\text {obs }}$ vs $\left[\mathrm{PMe}_{3}\right]$ gave the secondorder rate constant. Activation parameters were deduced from a graph of $\ln \left(k T^{-1}\right)$ vs $T^{-1}$ for $T=0,10,20$, and $30^{\circ} \mathrm{C}$ for reactions employing a 20 times excess of $\mathrm{PMe}_{3}$. The slope was taken as $\Delta H^{\ddagger} / R$ and the $y$ intercept as $\Delta S^{\ddagger} / R+23.8\left[=\ln \left(k_{\mathrm{b}} / h\right)\right]$. We estimate 5\% uncertainty in the rate constants. With this assumption, using only the rate constants for the 273 and $303 \mathrm{~K}$ reactions, we determined uncertainties in $\Delta H^{\ddagger}$ and $\Delta S^{\ddagger}$.

\section{$\left[\mathrm{Fe}_{2}\left(\mathrm{~S}_{2} \mathrm{C}_{2} \mathrm{H}_{4}\right)(\mu-\mathrm{CO})(\mathrm{CO})_{2}(\mathrm{dppv})\left(\mathrm{PMe}_{3}\right)(\mathrm{NCMe})\right]\left(\mathrm{PF}_{6}\right)_{2},\left[1(\mathrm{CO})_{3}-\left(\mathrm{PMe}_{3}\right)(\mathrm{NCMe})\right]\left(\mathrm{PF}_{6}\right)_{2}$}

A solution of $0.200 \mathrm{~g}(0.263 \mathrm{mmol})$ of $\mathbf{1}(\mathrm{CO})_{3}\left(\mathrm{PMe}_{3}\right)$ in $10 \mathrm{~mL}$ of $\mathrm{MeCN}$ was treated with a solution $0.174 \mathrm{~g}(0.526 \mathrm{mmol})$ of $\mathrm{Cp}_{2} \mathrm{FePF}_{6}$ in $5 \mathrm{~mL}$ of $\mathrm{MeCN}$. The reaction solution changed from dark red to green immediately. Solvent was removed in vacuum, and the green-colored residue was rinsed with $\sim 30 \mathrm{~mL}$ of hexane. The reaction mixture was extracted into $3 \mathrm{~mL}$ of $\mathrm{MeCN}$, and the product precipitated as a green powder upon the addition of $35 \mathrm{~mL}$ of $\mathrm{Et}_{2} \mathrm{O}$. Yield: $0.214 \mathrm{~g}(75 \%) .{ }^{1} \mathrm{H}$ NMR $\left(\mathrm{MeCN}_{-} \mathrm{d}_{3}\right): \delta 8.8-7.5\left(\mathrm{~m}, 20 \mathrm{H}, \mathrm{C}_{6} H_{5}\right), 4.40(\mathrm{~s}, 2 \mathrm{H}, \mathrm{PC} H)$, $3.40\left(\mathrm{~m}, 2 \mathrm{H}, \mathrm{SCH}_{2}\right), 3.03\left(\mathrm{~m}, 2 \mathrm{H}, \mathrm{SCH}_{2}\right) 1.85\left(\mathrm{~d}, \mathrm{~J}_{\mathrm{P}-\mathrm{H}}=12 \mathrm{~Hz}, 9 \mathrm{H}, \mathrm{PCH}_{3}\right) .{ }^{31} \mathrm{P} \mathrm{NMR}(\mathrm{MeCN}-$ $\left.d_{3}\right): \delta 74.6\left(\mathrm{~d}, J_{\mathrm{P}-\mathrm{P}}=5 \mathrm{~Hz}\right), 36.4\left(\mathrm{t}, J_{\mathrm{P}-\mathrm{P}}=5 \mathrm{~Hz}\right) . \mathrm{IR}(\mathrm{MeCN}): v_{\mathrm{CO}} 2061,2018,1909 \mathrm{~cm}^{-1}$. 
ESI-MS: $m / z$ 946.2 $\left(\left[\mathrm{Fe}_{2}\left(\mathrm{~S}_{2} \mathrm{C}_{2} \mathrm{H}_{4}\right)(\mu \text {-CO)(CO) })_{2}(\mathrm{dppv})\left(\mathrm{PMe}_{3}\right)(\mathrm{NCMe})\right] \mathrm{PF}_{6}{ }^{+}\right)$. Anal. Calcd for $\mathrm{C}_{36} \mathrm{H}_{38} \mathrm{Fe}_{2} \mathrm{NF}_{12} \mathrm{O}_{3} \mathrm{P}_{5} \mathrm{~S}_{2}$ (found): $\mathrm{C}, 39.60$ (39.31); H, 3.51 (3.45); N, 1.28 (1.24).

When a solution of $0.020 \mathrm{~g}(0.0263 \mathrm{mmol})$ of $\mathbf{1}(\mathrm{CO})_{3}\left(\mathrm{PMe}_{3}\right)$ in $5 \mathrm{~mL}$ of acetone was treated with $0.017 \mathrm{~g}(0.0526 \mathrm{mmol})$ of $\mathrm{Cp}_{2}-\mathrm{FePF}_{6}$ in $5 \mathrm{~mL}$ of acetone at $-40{ }^{\circ} \mathrm{C}$, the solution color changed from red to green. The IR spectrum indicated $\left[\mathrm{Fe}_{2}\left(\mathrm{~S}_{2} \mathrm{C}_{2} \mathrm{H}_{4}\right)(\mu-\mathrm{CO})-(\mathrm{CO})_{2}(\mathrm{dppv})\right.$ $\left.\left(\mathrm{PMe}_{3}\right)\left(\mathrm{OCMe}_{2}\right)\right]^{2+}$. IR $\left(\mathrm{OCMe}_{2}\right): v_{\mathrm{CO}} 2059,2015,1912 \mathrm{~cm}^{-1}$. Upon warming of the solution to $20^{\circ} \mathrm{C}$, the IR spectrum revealed that the complex had decomposed.

\section{$\left[\mathrm{Fe}_{2}\left(\mathrm{~S}_{2} \mathrm{C}_{2} \mathrm{H}_{4}\right)(\mu-\mathrm{CO})(\mathrm{CO})(\mathrm{dppv})\left(\mathrm{PMe}_{3}\right)_{\mathbf{2}}(\mathrm{NCMe})\right]\left(\mathrm{PF}_{6}\right)_{2},\left[\mathbf{1}(\mathrm{CO})_{2}-\left(\mathrm{PMe}_{3}\right)_{\mathbf{2}}(\mathrm{NCMe})\right]\left(\mathrm{PF}_{6}\right)_{2}$}

A solution of $0.280 \mathrm{~g}(0.368 \mathrm{mmol})$ of $\mathbf{1}(\mathrm{CO})_{3}\left(\mathrm{PMe}_{3}\right)$ in $10 \mathrm{~mL}$ of MeCN was treated with a solution of $0.243 \mathrm{~g}(0.736 \mathrm{mmol})$ of $\mathrm{Cp}_{2} \mathrm{FePF}_{6}$ in $5 \mathrm{~mL}$ of MeCN. The reaction mixture became green and was immediately treated with $1.2 \mathrm{~mL}(0.736 \mathrm{mmol})$ of a $0.59 \mathrm{M}$ solution of $\mathrm{PMe}_{3}$ in $\mathrm{MeCN}$. The solvent was removed in vacuum, and the dark-red residue was rinsed with $\sim 30$ $\mathrm{mL}$ of hexane. The solid was extracted into $3 \mathrm{~mL}$ of $\mathrm{MeCN}$; the product precipitated as a brown powder upon the addition of $35 \mathrm{~mL}$ of $\mathrm{Et}_{2} \mathrm{O}$. Yield: $0.285 \mathrm{~g}(68 \%) .{ }^{1} \mathrm{H} \mathrm{NMR}\left(\mathrm{MeCN}-d_{3}\right): \delta$ 8.7-7.3 (m, 20H, $\left.\mathrm{C}_{6} H_{5}\right), 4.40(\mathrm{~s}, 2 \mathrm{H}, \mathrm{PCH}), 3.40\left(\mathrm{~m}, 2 \mathrm{H}, \mathrm{SCH} \mathrm{H}_{2}\right), 2.91\left(\mathrm{~m}, 2 \mathrm{H}, \mathrm{SCH}_{2}\right), 2.53$ $\left(\mathrm{m}, 3 \mathrm{H}, \mathrm{Fe}-\mathrm{NCCH}_{3}\right), 1.43\left(\mathrm{~d}, J_{\mathrm{P}-\mathrm{H}}=10 \mathrm{~Hz}, 9 \mathrm{H}, \mathrm{PCH}_{3}\right), 1.20\left(\mathrm{~d}, J_{\mathrm{P}-\mathrm{H}}=11 \mathrm{~Hz}, 9 \mathrm{H}\right.$, $\left.\mathrm{PCH}_{3}\right) .{ }^{31} \mathrm{P} \mathrm{NMR}\left(\mathrm{MeCN}-d_{3}\right): \delta 74.5,68.7,24.3\left(\mathrm{t}, J_{\mathrm{P}-\mathrm{P}}=27 \mathrm{~Hz}\right), 17.2\left(\mathrm{t}, J_{\mathrm{P}-\mathrm{P}}=27 \mathrm{~Hz}\right) . \mathrm{IR}$ $(\mathrm{MeCN}): v_{\mathrm{CO}} 1983,1888 \mathrm{~cm}^{-1}$. ESI-MS: $m / z$. $994.4\left(\left[\mathrm{Fe}_{2}\left(\mathrm{~S}_{2} \mathrm{C}_{2} \mathrm{H}_{4}\right)(\mu-\mathrm{CO})(\mathrm{CO})(\mathrm{dppv})\right.\right.$ $\left.\left.\left(\mathrm{PMe}_{3}\right)(\mathrm{NCMe})\right]\left(\mathrm{PF}_{6}\right)^{+}\right)$.

\section{Oxidation of $\mathrm{Et}_{4} \mathrm{~N}\left[1(\mathrm{CN})(\mathrm{CO})_{3}\right]$ with $\mathrm{Cp}_{2} \mathrm{FePF}_{6}$}

A solution of $0.030 \mathrm{~g}(0.0357 \mathrm{mmol})$ of $\mathrm{Et}_{4} \mathrm{~N}\left[\mathbf{1}(\mathrm{CN})(\mathrm{CO})_{3}\right]$ in $10 \mathrm{~mL}$ of $\mathrm{MeCN}$ was treated with a solution of $0.023 \mathrm{~g}(0.0714 \mathrm{mmol})$ of $\mathrm{Cp}_{2} \mathrm{FePF}_{6}$ in $5 \mathrm{~mL}$ of $\mathrm{MeCN}$ at $-40{ }^{\circ} \mathrm{C}$ under a $\mathrm{CO}$ atmosphere. The solution was warmed to room temperature and the product spectroscopically identified as $\left[\mathrm{Fe}_{2}\left(\mathrm{~S}_{2} \mathrm{C}_{2} \mathrm{H}_{4}\right)(\mu-\mathrm{CO})(\mathrm{CN})(\mathrm{CO})_{2}(\mathrm{dppv})(\mathrm{NCMe})\right]^{+.}{ }^{1} \mathrm{H} \mathrm{NMR}$ $\left(\mathrm{MeCN}_{-} \mathrm{d}_{3}\right): \delta 8.8-7.3\left(\mathrm{~m}, 20 \mathrm{H}, \mathrm{PC}_{6} \mathrm{H}_{5}\right), 4.17(\mathrm{~s}, 2 \mathrm{H}, \mathrm{PCH}), 3.4\left(\mathrm{~m}, 2 \mathrm{H}, \mathrm{SCH}_{2}\right), 3.18(\mathrm{~m}, 2 \mathrm{H}$, $\left.\mathrm{SCH}_{2}\right) \cdot{ }^{31} \mathrm{P}$ NMR $\left(\mathrm{MeCN}-d_{3}\right): \delta 75.3$. IR $(\mathrm{MeCN}): v_{\mathrm{CN}} 2139,2121 \mathrm{~cm}^{-1} \cdot v_{\mathrm{CO}} 2068,2028$, $1895 \mathrm{~cm}^{-1}$. ESI-MS: $m / z, 751\left(\left[\mathrm{Fe}_{2}\left(\mathrm{~S}_{2} \mathrm{C}_{2} \mathrm{H}_{4}\right)(\mu-\mathrm{CO})(\mathrm{CN})(\mathrm{CO})_{2}(\mathrm{dppv})(\mathrm{NCMe})\right]^{+}\right)$.

\section{$\mathrm{Fe}\left(\mathrm{S}_{2} \mathrm{C}_{3} \mathrm{H}_{6}\right)(\mathrm{CO})_{3}(\mathrm{dppv})\left(\mathrm{PMe}_{3}\right), 2(\mathrm{CO})_{3}\left(\mathrm{PMe}_{3}\right)$, and Its Oxidation}

The preparation followed that described above for $1(\mathrm{CO})_{3}-\left(\mathrm{PMe}_{3}\right)$. Yield: $0.29 \mathrm{~g}(90 \%) .{ }^{1} \mathrm{H}$ NMR $\left(\mathrm{CDCl}_{2}\right): \delta 8.0-7.3\left(\mathrm{~m}, 20 \mathrm{H}, \mathrm{PC}_{6} H_{5}\right), 4.2(\mathrm{~s}, 2 \mathrm{H}, \mathrm{PCH}), 1.8\left(\mathrm{~m}, 2 \mathrm{H}, \mathrm{SCH}_{2}\right), 1.5(\mathrm{~m}, 2 \mathrm{H}$, $\left.\mathrm{SCH}_{2}\right), 1.36\left(\mathrm{~d}, J_{\mathrm{P}-\mathrm{H}}=8 \mathrm{~Hz}, 9 \mathrm{H}, \mathrm{PCH}_{3}\right), 1.2\left(\mathrm{~m}, 2 \mathrm{H}, \mathrm{CH}_{2} \mathrm{CH}_{2}-\mathrm{CH}_{2}\right) .{ }^{31} \mathrm{P} \mathrm{NMR}\left(\mathrm{CD}_{2} \mathrm{Cl}_{2}, 20\right.$ $\left.{ }^{\circ} \mathrm{C}\right): \delta 92.9,26.9 .{ }^{31} \mathrm{P} \mathrm{NMR}\left(\mathrm{CD}_{2}-\mathrm{Cl}_{2},-90{ }^{\circ} \mathrm{C}\right): \delta 101.6,96.4,91.7,90.2,84.8,34.2,28.3,26.7$. IR $\left(\mathrm{CH}_{2} \mathrm{Cl}_{2}\right): v_{\mathrm{CO}} 1943,1893 \mathrm{~cm}^{-1}$. FD-MS: $m / z$. $774.6\left(\left[\mathrm{Fe}\left(\mathrm{S}_{2} \mathrm{C}_{3} \mathrm{H}_{6}\right)-(\mathrm{CO})_{3}(\mathrm{dppv})\right.\right.$ $\left.\left.\left(\mathrm{PMe}_{3}\right)\right]^{+}\right)$.

When a solution of $0.075 \mathrm{~g}(0.097 \mathrm{mmol})$ of $2(\mathrm{CO})_{3}\left(\mathrm{PMe}_{3}\right)$ in $10 \mathrm{~mL}$ of MeCN was treated with $0.064 \mathrm{~g}(0.194 \mathrm{mmol})$ of $\mathrm{Cp}_{2}-\mathrm{FePF}_{6}$ in $5 \mathrm{~mL}$ of $\mathrm{MeCN}$ at $-40{ }^{\circ} \mathrm{C}$ under a $\mathrm{CO}$ atmosphere, the solution color changed from red to green. The IR spectrum indicated $\left[\mathrm{Fe}_{2}\left(\mathrm{~S}_{2} \mathrm{C}_{3} \mathrm{H}_{6}\right)(\mu-\mathrm{CO})\right.$ $\left.(\mathrm{CO})_{2}\left(\mathrm{PMe}_{3}\right)(\mathrm{dppv})(\mathrm{NCMe})\right]^{2+}$. IR $(\mathrm{MeCN}): v_{\mathrm{CO}} 2055,2009,1922 \mathrm{~cm}^{-1}$. Upon warming of the solution to $20^{\circ} \mathrm{C}$, the IR spectrum revealed that the complex had decomposed.

\section{X-ray Crystallography}

Crystals were mounted to a thin glass fiber using Paratone-N oil (Exxon). Data, collected at $198 \mathrm{~K}$ on a Siemens CCD diffractometer, were filtered to remove statistical outliers. The integration software (SAINT) was used to test for crystal decay as a bilinear function of X-ray exposure time and $\sin (\Theta)$. The data were solved using SHELXTL by direct methods (Table 1); atomic positions were deduced from an $E$ map or by an unweighted difference Fourier 
synthesis. Hydrogen atom $U$ 's were assigned as $1.2 \mathrm{Ueq}$ for adjacent carbon atoms. Nonhydrogen atoms were refined anisotropically. Successful convergence of the full-matrix leastsquares refinement of $F^{2}$ was indicated by the maximum shift/error for the final cycle.

\section{DFT Calculations}

DFT calculations used both the BP86 28,29 functional and a valence triple- $\zeta$ basis set with polarization on all atoms (TZVP). ${ }^{30}$ Stationary points of the energy hypersurface were located using energy gradient techniques, and full vibrational analysis has been carried out to further characterize each stationary point. Free energy values have been obtained from the electronic self-consistent-field energy considering three contributions to the total partition function $(Q)$, namely, $q_{\text {translational }}, q_{\text {rotational }}, q_{\text {vibrational }}$, under the assumption that $Q$ may be written as the product of such terms. Solvation effects $\left(\mathrm{CH}_{3} \mathrm{CN} ; \varepsilon=37.5\right)$ have been evaluated according to the COSMO approach.

\section{Acknowledgements}

This work was supported by the National Institutes of Health and the Petroleum Research Fund. We thank Terésa Prussak-Wieckowska for assistance with the crystallographic analyses.

\section{References}

1. Basic Research Needs for the Hydrogen Economy. Report of the Basic Energy Sciences Workshop on Hydrogen Production, Storage, and Use.

2. Tye JW, Hall MB, Darensbourg MY. Proc Natl Acad Sci 2005;102:16911-16912. [PubMed: 16286638]

3. Linck, RC.; Rauchfuss, TB. Bioorganometallics: Biomolecules, Labeling, Medicine. Jaouen, G., editor. Wiley-VCH; Weinheim, Germany: 2005.

4. Cammack, R.; Frey, M.; Robson, R. Hydrogen as a Fuel: Learning from Nature. Taylor \& Francis; London: 2001.

5. Frey M. Chem Bio Chem 2002;3:153-160.

6. Lawrence JD, Rauchfuss TB, Wilson SR. Inorg Chem 2002;41:6193-6195. [PubMed: 12444758]

7. de Beer JA, Haines RJ. J Organomet Chem 1972;36:297-312.

8. Lyon EJ, Georgakaki IP, Reibenspies JH, Darensbourg MY. Angew Chem, Int Ed 1999;38:31783180.Schmidt M, Contakes SM, Rauchfuss TB. J Am Chem Soc 1999;121:9736-9737.

9. Vahrenkamp H, Geiß A, Richardson GN. J Chem Soc Dalton Trans 1997:3643-3651.

10. van der Vlugt JI, Rauchfuss TB, Wilson SR. Chem -Eur J 2005;12:90-98.

11. Li P, Wang M, He C, Li G, Liu X, Chen C, Åkermark B, Sun L. Eur J Inorg Chem 2005:2506-2513.

12. Song LC, Yang ZY, Bian HZ, Hu QM. Organometallics 2004;23:3082-3084.Song LC, Yang ZY,

Bian HZ, Liu Y, Wang HT, Liu XF, Hu QM. Organometallics 2005;24:6126-6135.Hogarth G,

O'Brien M, Tocher DA. J Organomet Chem 2003;672:29-33.de Beer JA, Haines RJ, Greatrex R, Greenwood NN. J Chem Soc 1971:3271-3282.Hossain GMG, Hyder MI, Kabir SE, Abdul Malik KM, Miah MA, Siddiquee TA. Polyhedron 2003;22:633-640.

13. de Beer JA, Haines RJ, Greatex R, Greenwood NN. J Organomet Chem 1971;27:C33-C35.

14. Song LC, Yan CG, Mao XA. Gaodeng Xuexiao Huaxue Xuebao 1997;18:1093-1097.

15. Tye JW, Lee J, Wang HW, Mejia-Rodriguez R, Reibenspies JH, Hall MB, Darensbourg MY. Inorg Chem 2005;44:5550-5552. [PubMed: 16060601]Ekström J, Ott S, Sun L, Åkermark B, Eriksson L. Acta Crystallogr, Sect E 2005;E61:m852-m853.

16. Lawrence JD, Li H, Rauchfuss TB, Bénard M, Rohmer M-M. Angew Chem Int Ed 2001;40:17681771.

17. Ellgen PC, Gerlach JN. Inorg Chem 1973;12:2526-2532.

18. Lyon EJ, Georgakaki IP, Reibenspies JH, Darensbourg MY. J Am Chem Soc 2001;123:3268-3278. [PubMed: 11457062] 
19. Zampella G, Bruschi M, Fantucci P, Razavet M, Pickett CJ, De Gioia L. Chem- Eur J 2005;11:509_ 520.

20. Georgakaki IP, Thomson LM, Lyon EJ, Hall MB, Darensbourg MY. Coord Chem Rev 2003;238239:255-266.

21. Corrections to energy barriers led, for the reaction between $1(\mathrm{CO})_{4}$ and $\mathrm{PMe}_{3}$, to a computed $\Delta G^{\ddagger}$ at $298 \mathrm{~K}$ of $24.4 \mathrm{kcal} / \mathrm{mol}$, which is in reasonable agreement with experimental data, considering that the BP86 functional is known to underestimate reaction barriers.

22. Boyke CA, Rauchfuss TB, Wilson SR, Rohmer MM, Bénard M. J Am Chem Soc 2004;126:1515115160. [PubMed: 15548012]

23. Boyke CA, van der Vlugt JI, Rauchfuss TB, Wilson SR, Zampella G, De Gioia L. J Am Chem Soc 2005;127:11010-11018. [PubMed: 16076208]

24. Bruschi M, Fantucci P, De Gioia L. Inorg Chem 2004;43:3733-3741. [PubMed: 15180430]

25. Tye JW, Darensbourg MY, Hall MB. Inorg Chem 2006;45:1552-1559. [PubMed: 16471966]

26. Adams RD, Cotton FA, Cullen WR, Hunter DL, Mihichuk L. Inorg Chem 1975;14:1395-1399.Flood TC, DiSanti FJ, Campbell KD. Inorg Chem 1978;17:1643-1646.

27. Li H, Rauchfuss TB. J Am Chem Soc 2002;124:726-727. [PubMed: 11817928]

28. Becke AD. Phys Rev A: Gen Phys 1988;38:3098-3100.Perdew JP. Phys Rev 1986;B33:8822-8824.

29. Schaefer A, Huber C, Ahlrichs R. J Chem Phys 1994;100:5829-5835.

30. Klamt A. J Phys Chem 1996;100:3349.Klamt A. J Phys Chem 1995;99:2224. 


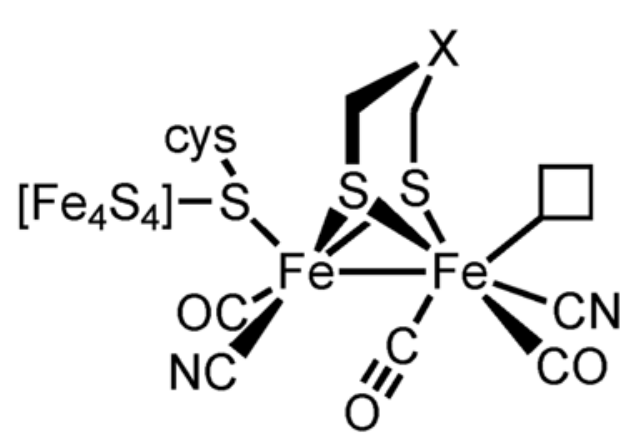

$\mathrm{H}_{\text {red }}$

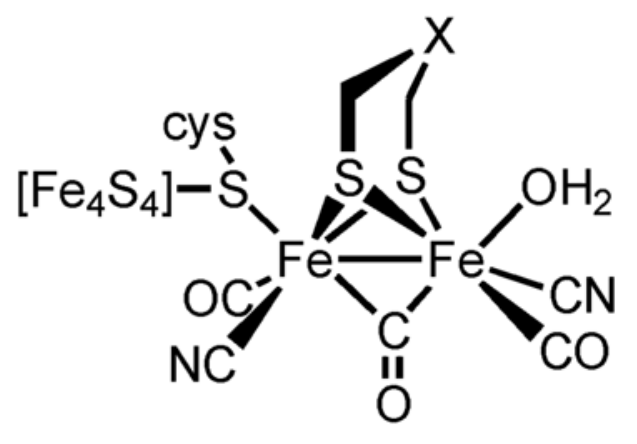

$\mathrm{H}_{\mathrm{ox}}$

Figure 1.

Active site of the $[\mathrm{Fe}-\mathrm{Fe}]^{-}$hydrogenase in the reduced and oxidized forms. ${ }^{5}$ 


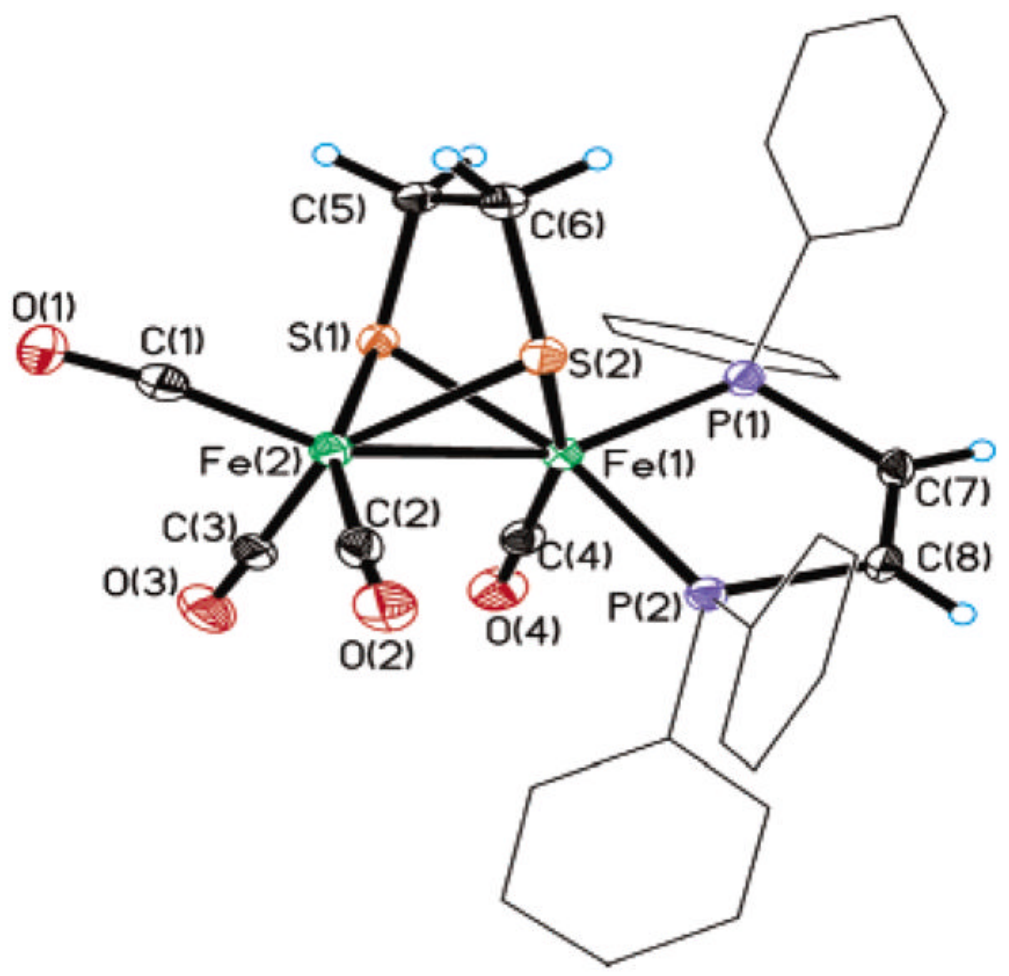

Figure 2.

Structure of $\mathbf{1}(\mathrm{CO})_{4}$, with thermal ellipsoids set at $35 \%$. Phenyl ellipsoids and phenyl hydrogen atoms have been omitted. Selected bond lengths ( $\AA$ ) and angles (deg): $\mathrm{Fe}(1)-\mathrm{Fe}(2), 2.5249(9)$; $\mathrm{Fe}(1)-\mathrm{S}(1), 2.2451-(13) ; \mathrm{Fe}(1)-\mathrm{S}(2), 2.2575(13) ; \mathrm{Fe}(1)-\mathrm{P}(1), 2.1743(13) ; \mathrm{Fe}(1)-\mathrm{P}(2)$, 2.2070-(13); $\mathrm{Fe}(1)-\mathrm{C}(4), 1.754(5) ; \mathrm{Fe}(2)-\mathrm{C}(1), 1.783(5) ; \mathrm{Fe}(2)-\mathrm{C}(2), 1.779(5) ; \mathrm{Fe}(2)-\mathrm{C}(3)$, 1.780(5); $\mathrm{Fe}(2)-\mathrm{Fe}(1)-\mathrm{P}(1), 154.05(5) ; \mathrm{Fe}(2)-\mathrm{Fe}(1)-\mathrm{P}(2), 109.23(4) ; \mathrm{Fe}(2)-\mathrm{Fe}(1)-\mathrm{C}(4)$, 105.11(15); P(1)-Fe(1)-P(2), 87.83(5); P(1)-Fe(1)-C(4), 94.32(15); P(2)-Fe(1)-C(4), 88.88 (15). 


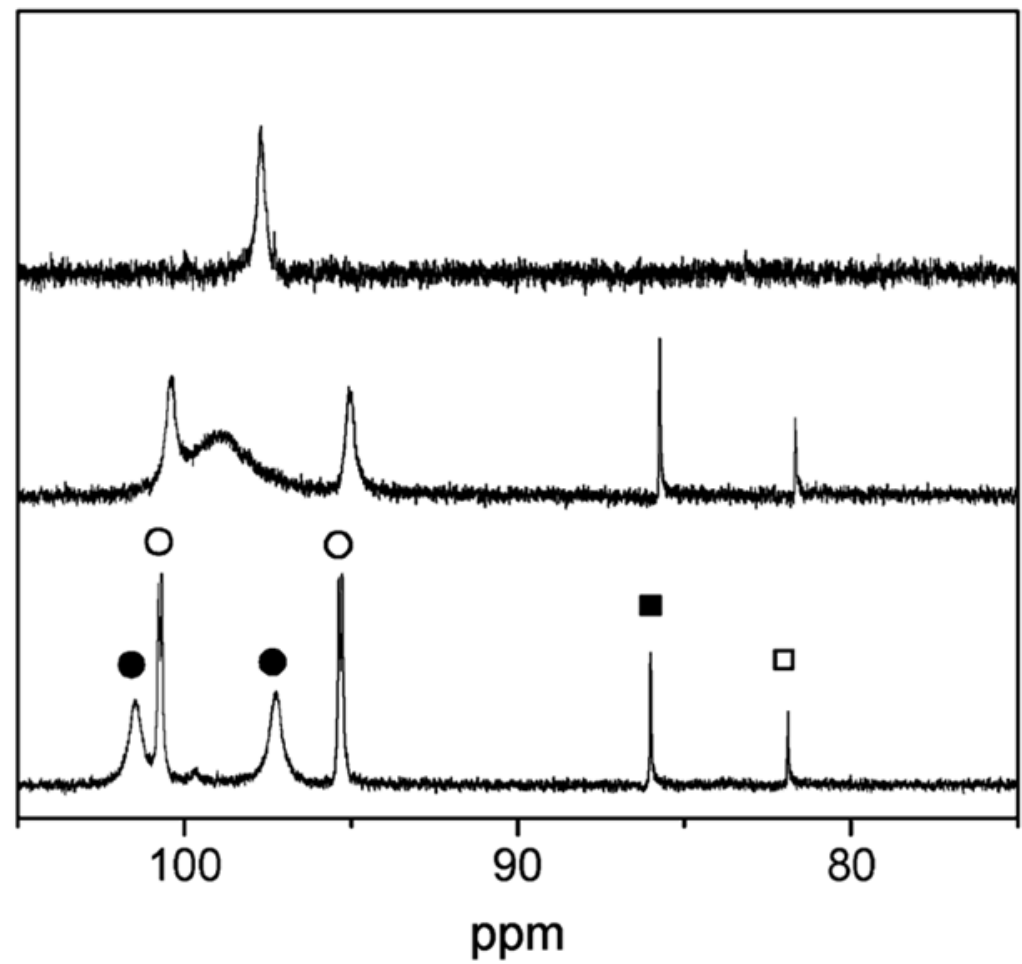

Figure 3.

${ }^{31} \mathrm{P}$ NMR spectra of $\mathrm{Fe}_{2}\left[\left(\mathrm{SCH}_{2}\right)_{2} \mathrm{NH}\right](\mathrm{CO})_{4}(\mathrm{dppv})$ in a $\mathrm{CD}_{2} \mathrm{Cl}_{2}$ solution at temperatures of +20 (top), -40 , and $-60{ }^{\circ} \mathrm{C}$ (bottom). 




$\Delta \mathrm{E}=0.0$

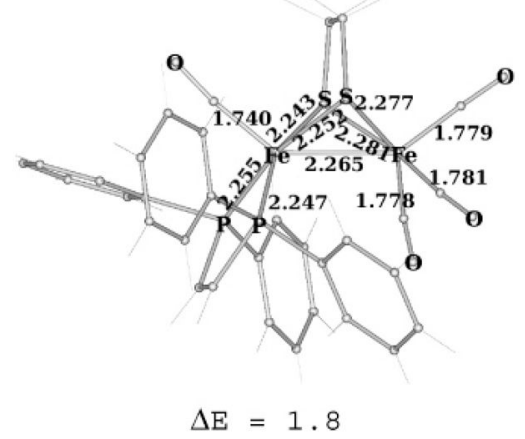

Figure 4.

Axial-basal (left) and dibasal (right) isomers of $\mathrm{Fe}_{2}(\mathrm{edt})(\mathrm{CO})_{4}(\mathrm{dppv})$ as obtained by DFT calculations (distances in angstroms and computed energy differences in kilocalories per mole relative to the more stable isomer). 


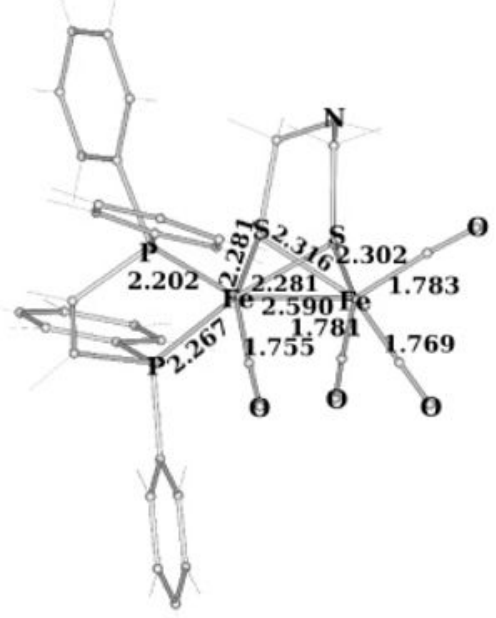

$\Delta \mathrm{E}=0.4$

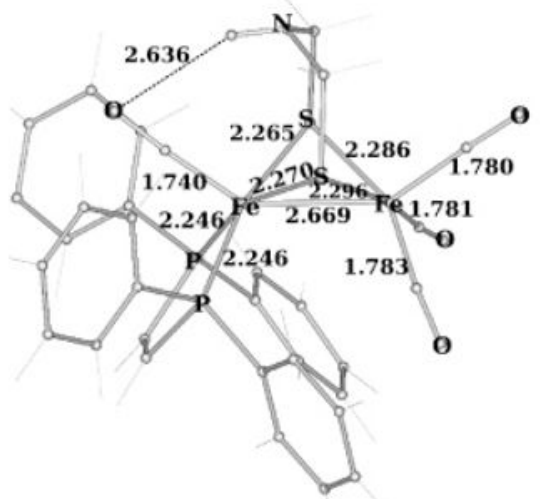

$\Delta \mathrm{E}=0.0$

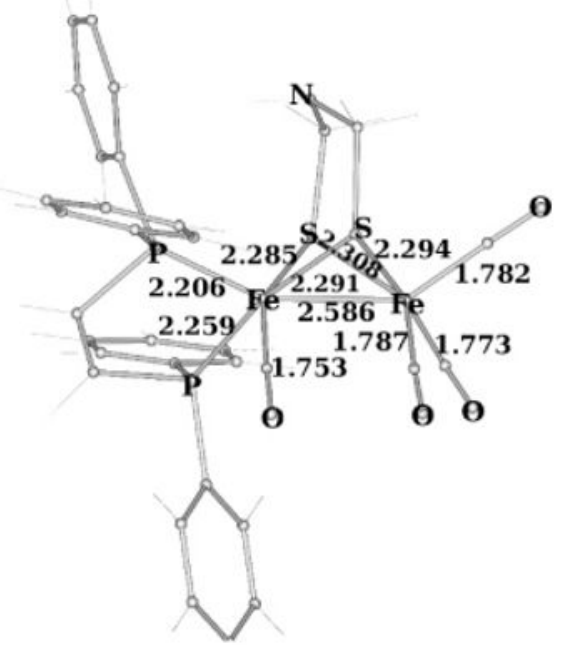

$\Delta \mathrm{E}=0.7$

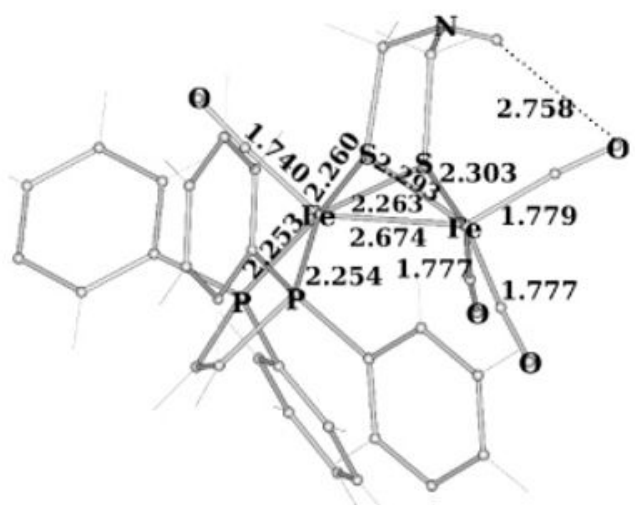

$\Delta \mathrm{E}=0.0$

Figure 5.

Axial-basal (top) and dibasal (bottom) isomers of $\mathrm{Fe}_{2}(\mathrm{adt})(\mathrm{CO})_{4}(\mathrm{dppv})$, as obtained by DFT calculations (distances in angstroms and computed energy differences in kilocalories per mole relative to the most stable isomer). 

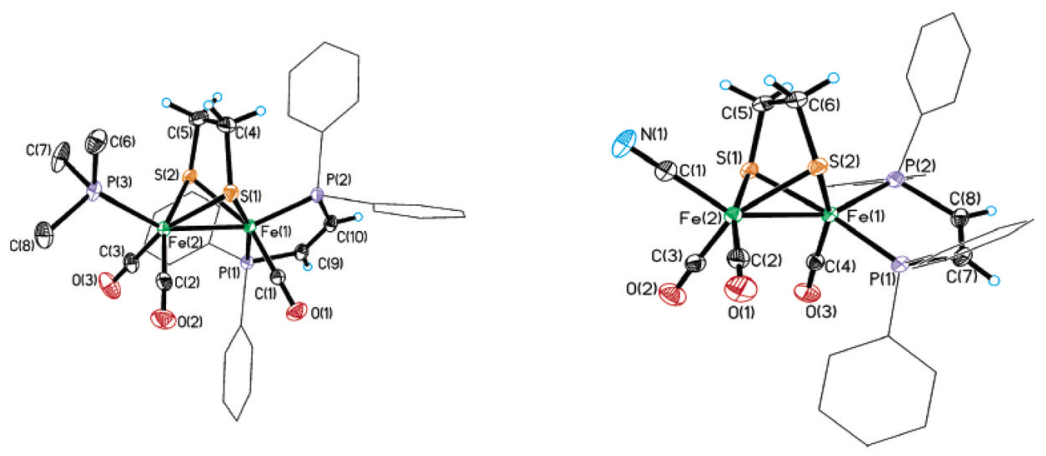

Figure 6.

Left: structure of $\mathbf{1}(\mathrm{CO})_{3}\left(\mathrm{PMe}_{3}\right)$ with thermal ellipsoids set at $35 \%$. Phenyl ellipsoids and

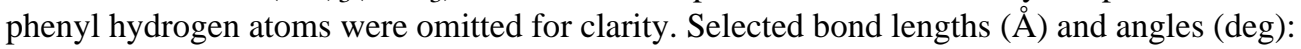
$\mathrm{Fe}(1)-\mathrm{Fe}(2), 2.5344(7) ; \mathrm{Fe}(1)-\mathrm{S}(1), 2.2633(11) ; \mathrm{Fe}(1)-\mathrm{S}(2), 2.2690(10) ; \mathrm{Fe}(1)-\mathrm{P}(1), 2.2006$ (11); $\mathrm{Fe}(1)-\mathrm{P}(2), 2.1918(10) ; \mathrm{Fe}(1)-\mathrm{C}(1), 1.755(4) ; \mathrm{Fe}(2)-\mathrm{P}(3), 2.2312(11) ; \mathrm{Fe}(2)-\mathrm{C}(2)$, 1.767(4); $\mathrm{Fe}(2)-\mathrm{C}(3), 1.758(4) ; \mathrm{Fe}(2)-\mathrm{Fe}(1)-\mathrm{P}(1), 108.38(3) ; \mathrm{Fe}(2)-\mathrm{Fe}-(1)-\mathrm{P}(2), 157.03(4)$; $\mathrm{Fe}(2)-\mathrm{Fe}(1)-\mathrm{C}(1), 101.08(12) ; \mathrm{P}(2)-\mathrm{Fe}(1)-\mathrm{P}(1), 88.19(4) ; \mathrm{P}(2)-\mathrm{Fe}(1)-\mathrm{C}(1), 93.97(12)$; C(1)$\mathrm{Fe}(1)-\mathrm{P}(1), 91.82(13)$. Right: structure of the anion in $\mathrm{Et}_{4} \mathrm{~N}\left[\mathbf{1}(\mathrm{CN})(\mathrm{CO})_{3}\right]$, with thermal ellipsoids set at 35\%. Phenyl ellipsoids, phenyl hydrogen atoms, and the $\mathrm{Et}_{4} \mathrm{~N}^{+}$groups are not shown. Selected bond lengths (̊) and angles (deg): $\mathrm{Fe}(1)-\mathrm{Fe}(2), 2.5416(16) ; \mathrm{Fe}(1)-\mathrm{S}(1)$, 2.2453(12); $\mathrm{Fe}(1)-\mathrm{S}(2), 2.2512(12)$; $\mathrm{Fe}(1)-\mathrm{P}(1), 2.1828(13) ; \mathrm{Fe}(1)-\mathrm{P}(2), 2.1763(12)$; $\mathrm{Fe}(1)-$ $\mathrm{C}(4), 1.733(3) ; \mathrm{Fe}(2)-\mathrm{C}(1), 1.916(3) ; \mathrm{Fe}(2)-\mathrm{C}(2), 1.766(3) ; \mathrm{Fe}(2)-\mathrm{C}(3), 1.751(3) ; \mathrm{Fe}(2)-\mathrm{Fe}$ (1)-P(1), 112.81(5); Fe(2)-Fe(1)-P(2), 154.49(3); Fe(2)-Fe(1)-C(4), 101.07(10); $\mathrm{P}(2)-\mathrm{Fe}$ (1)-P(1), 87.54(6); P(2)-Fe(1)-C(4), 94.50(10); P(1)-Fe(1)-C(4), 88.25(9). 


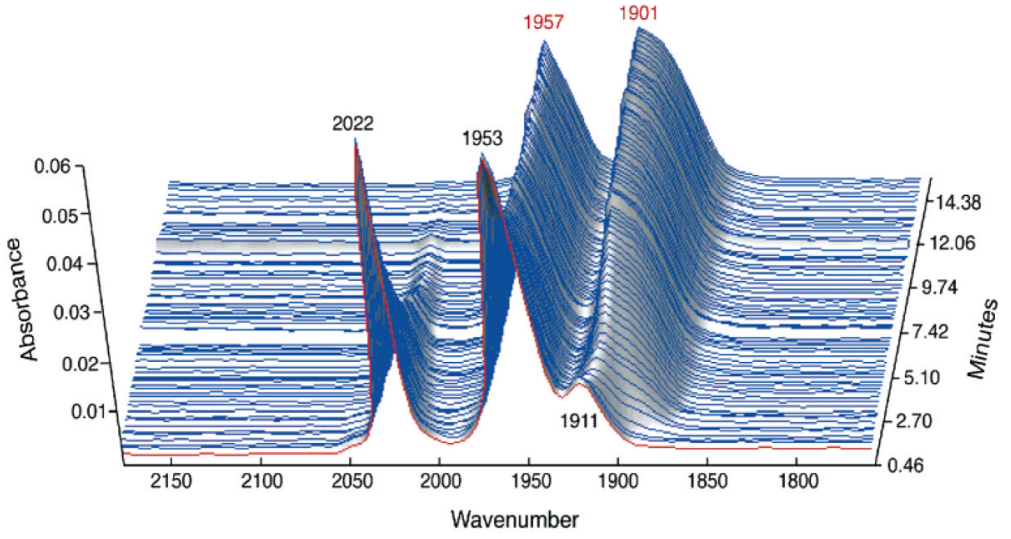

Figure 7.

IR spectra for the reaction of $\mathrm{Fe}_{2}\left(\mathrm{~S}_{2} \mathrm{C}_{2} \mathrm{H}_{4}\right)(\mathrm{CO})_{4}(\mathrm{dppv})(0.014 \mathrm{M})$ with 20 equiv of $\mathrm{PMe}_{3}$ in a $\mathrm{CH}_{2} \mathrm{Cl}_{2}$ solution at $20^{\circ} \mathrm{C}$. 

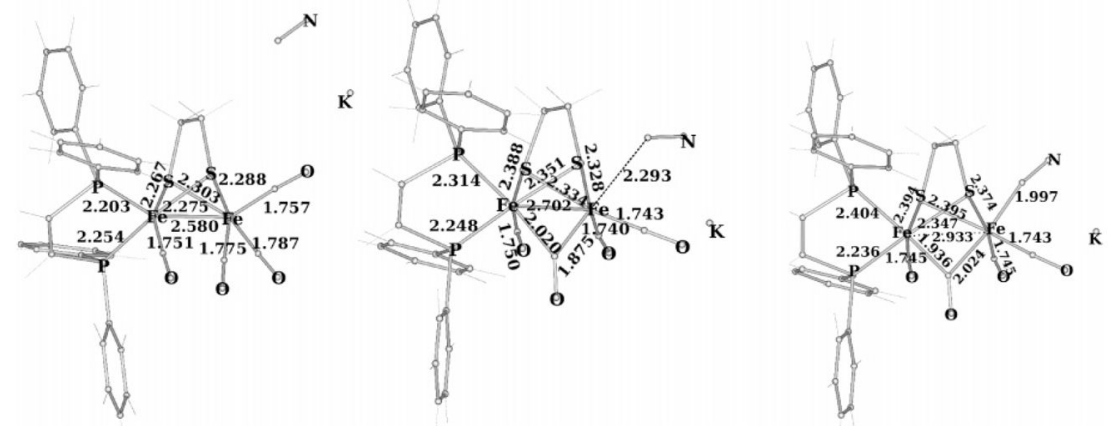

Figure 8.

DFT-optimized reactant, transition state, and product for the reaction $\mathbf{1}(\mathrm{CO})_{4}+\mathrm{KCN}$ (distances in angstroms). 




$\Delta \mathrm{E}=0.0$

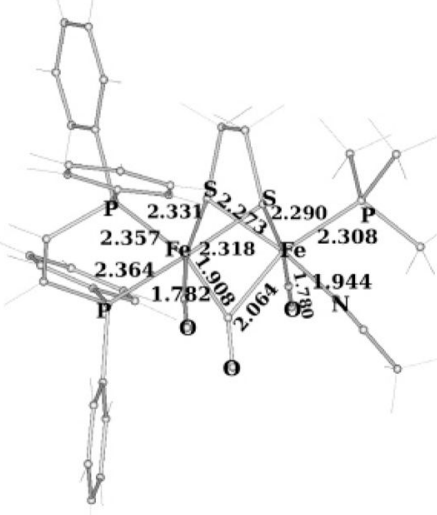

$\Delta \mathrm{E}=3.0$

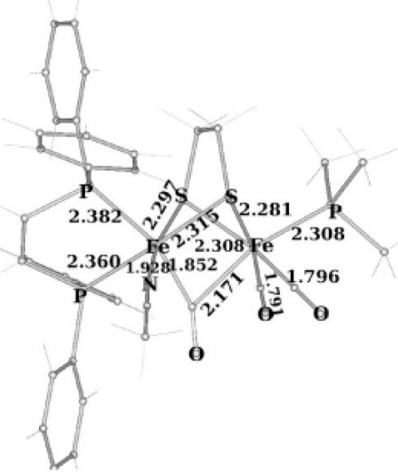

$\Delta \mathrm{E}=5.9$

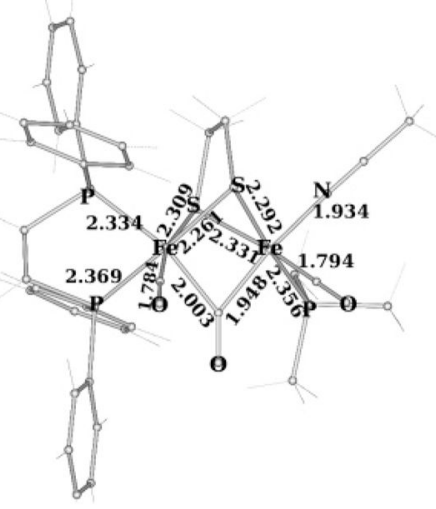

$\Delta \mathrm{E}=1.2$

Figure 9.

DFT-optimized structures of axial-basal and dibasal isomers of $\left[\mathrm{Fe}_{2}\left(\mathrm{~S}_{2} \mathrm{C}_{2} \mathrm{H}_{4}\right)(\mu\right.$-CO) $\left.(\mathrm{CO})_{2}(\mathrm{dppv})\left(\mathrm{PMe}_{3}\right)(\mathrm{NCMe})\right]^{2+}$ (distances in angstroms and computed energy differences in kilocalories per mole relative to the most stable isomer). For the sake of brevity, only the four most relevant (and most stable) isomers are shown. 


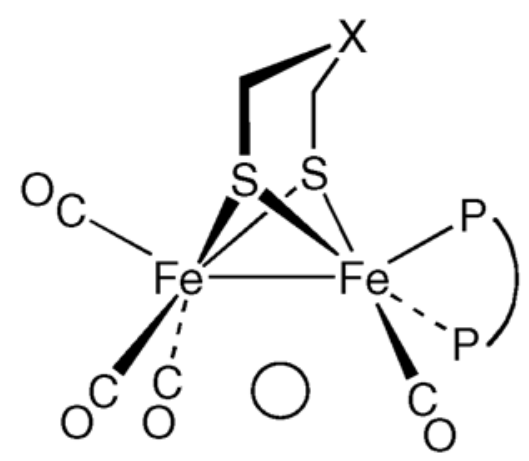

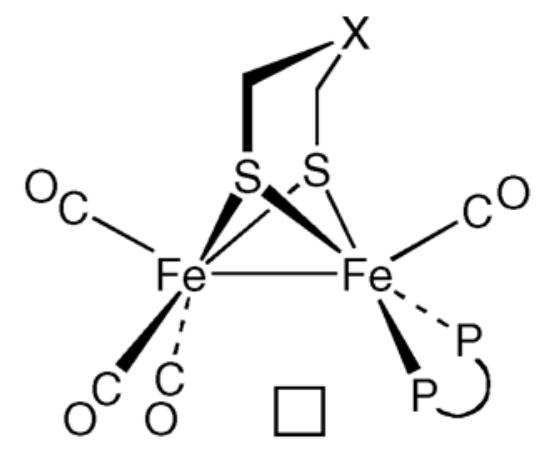

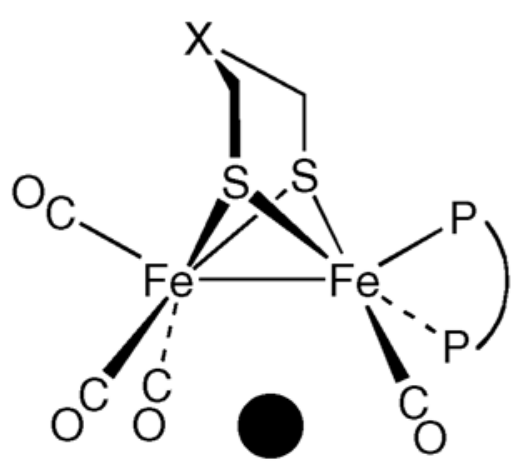

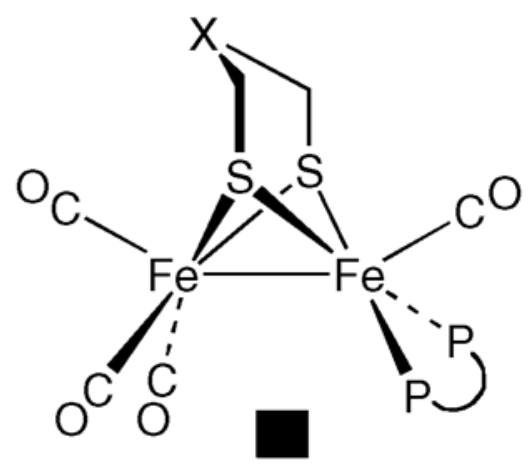

Scheme 1. 


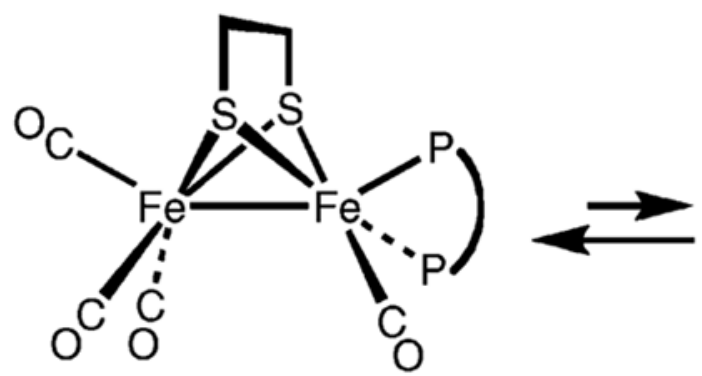

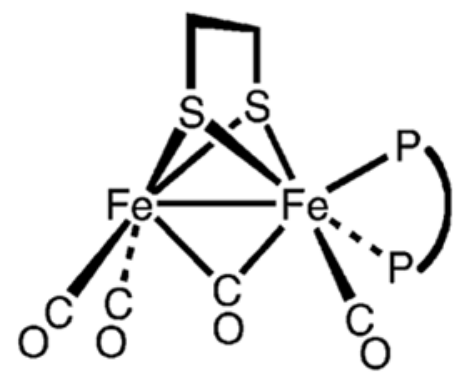

"rotated structure"

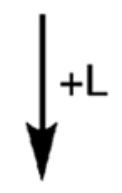

<smiles>CCC=O</smiles>

Scheme 2. 
Table 1

Details of Data Collection and Structure Refinement for Crystallography

\begin{tabular}{|c|c|c|c|}
\hline Complex & $\mathbf{1}(\mathrm{CO})_{4}$ & $\mathbf{1}(\mathrm{CO})_{3}\left(\mathrm{PMe}_{3}\right)$ & $\mathrm{Et}_{4} \mathrm{~N}\left[\mathbf{1}(\mathrm{CN})(\mathrm{CO})_{3}\right]$ \\
\hline chemical formula & $\mathrm{C}_{32} \mathrm{H}_{26} \mathrm{O}_{4} \mathrm{P}_{2} \mathrm{~S}_{2} \mathrm{Fe}_{2}$ & $\mathrm{C}_{34} \mathrm{H}_{35} \mathrm{O}_{3} \mathrm{P}_{3} \mathrm{~S}_{2} \mathrm{Fe}_{2}$ & $\mathrm{C}_{40} \mathrm{H}_{46} \mathrm{Fe}_{2} \mathrm{~N}_{2} \mathrm{O}_{3} \mathrm{P}_{2} \mathrm{~S}_{2}$ \\
\hline$T(\mathrm{~K})$ & $193(2)$ & $193(2)$ & $193(2)$ \\
\hline cryst size $\left(\mathrm{mm}^{3}\right)$ & $0.46 \times 0.08 \times 0.06$ & $0.16 \times 0.12 \times 0.01$ & $0.48 \times 0.36 \times 0.14$ \\
\hline cryst syst & triclinic & triclinic & Triclinic \\
\hline space group & $P 1^{-}$ & $P 1^{-}$ & $P 1^{-}$ \\
\hline$a(\AA)$ & $9.5119(15)$ & $10.4617(10)$ & $11.219(7)$ \\
\hline$b(\AA)$ & $12.1329(19)$ & $12.3125(10)$ & $11.505(7)$ \\
\hline$c(\AA)$ & $28.710(5)$ & $15.2256(13)$ & $18.994(12)$ \\
\hline$\alpha(\operatorname{deg})$ & $79.242(3)$ & $76.276(5)$ & $88.297(10)$ \\
\hline$\beta(\operatorname{deg})$ & $89.738(3)$ & $88.122(5)$ & $74.230(10)$ \\
\hline$\gamma(\mathrm{deg})$ & $83.877(3)$ & $89.143(4)$ & $66.601(9)$ \\
\hline$V\left(\AA^{3}\right)$ & $3236.1(9)$ & 1904.1(3) & $2157(2)$ \\
\hline$Z$ & 1 & 2 & 2 \\
\hline$D_{\text {calcd }}\left(\mathrm{Mg} \mathrm{m}^{-3}\right)$ & 1.509 & 1.474 & 1.425 \\
\hline$\mu(\mathrm{Mo} \mathrm{K} \alpha)\left(\mathrm{mm}^{-1}\right)$ & 0.71073 & 0.71073 & 0.71073 \\
\hline $\mathrm{max} / \mathrm{min}$ transmn & $0.9386 / 0.4782$ & $0.9767 / 0.8247$ & $0.8773 / 0.5901$ \\
\hline reflns measd/indep & $34970 / 12272$ & $58398 / 9444$ & $18473 / 7884$ \\
\hline data/restraints/parameters & $12272 / 0 / 770$ & $9444 / 0 / 427$ & $7884 / 66 / 519$ \\
\hline GOF on $F^{2}$ & 0.916 & 1.048 & 1.026 \\
\hline$R_{\text {int }}$ & 0.0931 & 0.0513 & 0.0335 \\
\hline $\mathrm{R} 1[I>2 \sigma]$ (all data) ${ }^{a}$ & $0.0513(0.1268)$ & $0.0518(0.0824)$ & $0.0374(0.0603)$ \\
\hline wR2 $[I>2 \sigma]$ (all data) $b$ & $0.0901(0.1070)$ & $0.1357(0.1532)$ & $0.0862(0.0944)$ \\
\hline max peak/hole $\left(\mathrm{e}^{-} / \AA^{3}\right)$ & $0.565 /-0.411$ & $0.834 /-1.189$ & $0.569 /-0.335$ \\
\hline
\end{tabular}

$a_{\mathrm{R} 1=\Sigma\left|F_{\mathrm{O}}\right|-\left|F_{\mathrm{C}}\right| \Sigma\left|F_{\mathrm{O}}\right|}$

$b_{\mathrm{wR} 2}=\left\{\left[w\left(\left|F_{\mathrm{O}}\right|-\left|\mathrm{F}_{\mathrm{C}}\right|\right)^{2}\right] / \Sigma\left[w F_{\mathrm{O}}^{2}\right]\right\}^{1 / 2}$, where $w=1 / \sigma^{2}\left(F_{\mathrm{O}}\right)$. 